\title{
Thanks for the Memories: The Athenian Agora as a Lieu de Mémoire
}

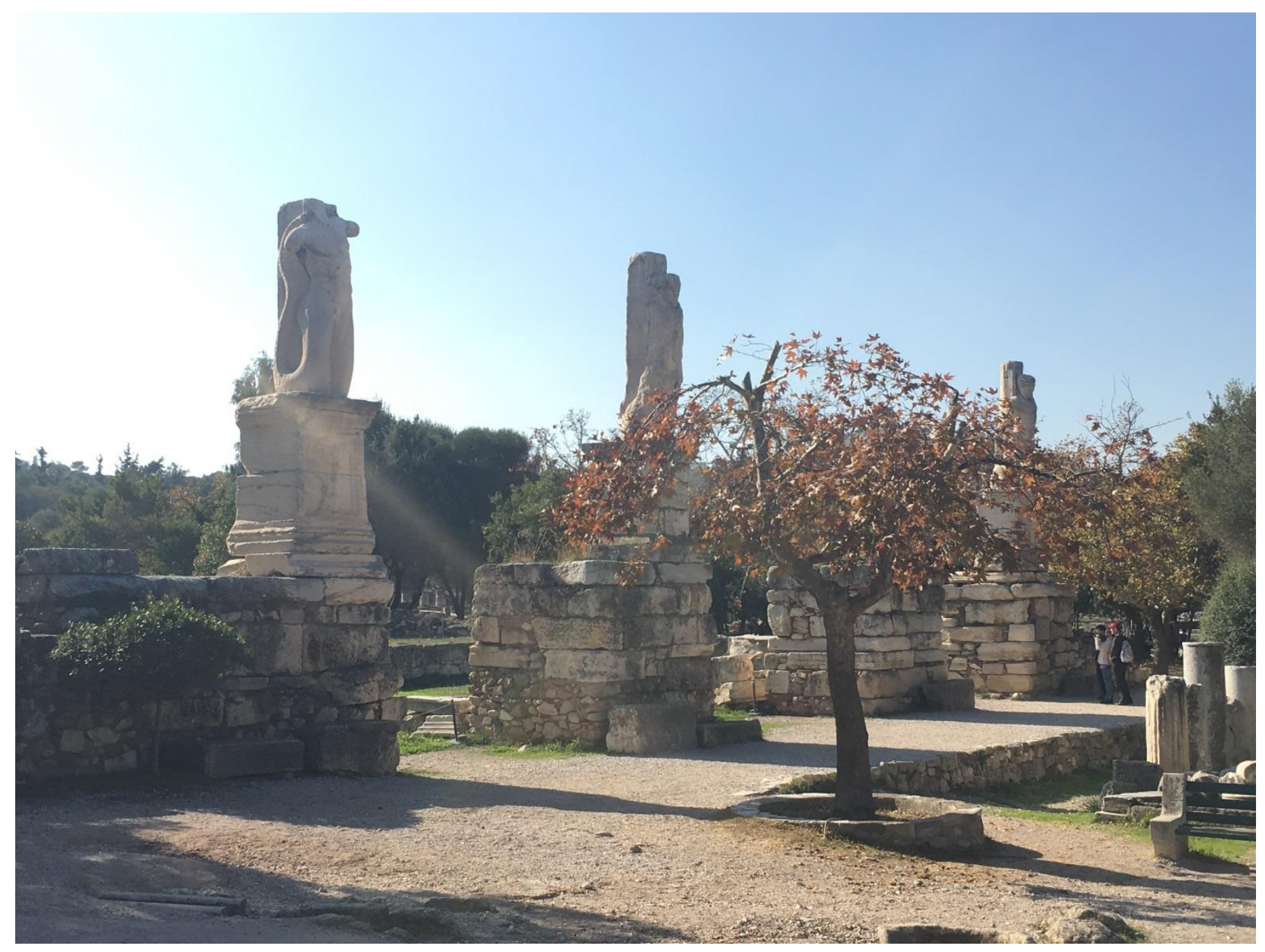

Ziming Liu

A thesis submitted to the Victoria University of Wellington in fulfilment of the requirements for the Master of Arts.

Victoria University of Wellington

2019 
Cover Image: Photograph of the Athenian Agora in November 2016 by the author. 



\section{Acknowledgements}

The greatest part of my thanks goes to my fearless supervisor - Dr. James Kierstead. My appreciation for James is by no means limited to his capacity as my supervisor over the past year. I am eternally grateful for his support throughout my journey at Victoria. For the past six

years, James has always believed in, encouraged, and pushed me to be the best version of myself as a scholar - all while being nothing but supportive, kind, and understanding. His advice has forever changed the path of my life, and I would not be where I am today without him. Of course, I would like to extend this gratitude to every single faculty member of the Victoria University Classics department. All of them have inspired, challenged, and encouraged me during my time here and I am proud to have been their student. I hope to one day, be even a fraction of the dedicated educators they are and I will miss them dearly.

Next, I would like to say thanks to Theo and Richard, because apparently I am contractually obliged to thank people who helped proofread my thesis. I think by this point, Theo has suffered through so much of my writing that he knows how to write like me better than I do. Richard was there too I guess. Thanks guys, I am always here to return the favour. Though in all seriousness, I could not have done this without you both - and I don't just mean the writing since anyone can proofread. Thanks for picking me off the ground when I'm sad (and kicking me right back down with your feedback)!

I know everyone says that they have the greatest friends in the world, but it is an objective fact that my friends are the best. I love you all, and thinking about you makes me not want to leave so this is all the thanks you get for now.

As always, thanks to my students past and present. You are the reason I do this.

Oh, and thanks to my father for raising me and making sure I eat enough fruit. 
For Wellington - my HOME. 



\section{Table of Contents}

$\begin{array}{lr}\text { Introduction } & 1\end{array}$

$\begin{array}{ll}\text { Methodology and the City of Memory } & 7\end{array}$

$\begin{array}{ll}\text { The Athenian Agora and its Monuments } & 23\end{array}$

The Age of Constitutional Turmoil $\quad 54$

$\begin{array}{ll}\text { Conclusion } & 76\end{array}$

$\begin{array}{ll}\text { List of Figures } & 78\end{array}$

$\begin{array}{lr}\text { Bibliography } & 82\end{array}$ 


\section{Introduction}

The relationship between memory and place can often be expressed through association. When one thinks of the birthplace of democracy, it does not tax the imagination for Athens and the Athenian Agora to spring to mind. The fact that the connection between the agora and democracy is so embedded in the collective consciousness even today is no coincidence. Rather, it is evidence of a naturally occurring space at the foot of the Athenian Akropolis undergoing several millennia of transformative experiences, shaping and being shaped by the identities of its inhabitants, in order to become the place now recognised as the Athenian Agora: the heart of Athens, the birthplace of democracy, and truly, a lieu de mémoire. ${ }^{1} \mathrm{~A}$ transformative process, which I argue, began at the end of $6^{\text {th }}$ century Athens with the collapse of the Peisistratid tyranny and was only strengthened by the advent of oligarchy in the final decade of the $5^{\text {th }}$ century. ${ }^{2}$

Several questions lie at the heart of this thesis. Firstly, how does understanding the Athenian Agora as a place of memory contribute to contemporary studies of Athenian history? Secondly, how did the Athenian constitutional changes in the period between 411 and 403 manifest themselves in the civic space? Finally, how did the transformations of the agora affect the efficacy of the infamous Athenian Amnesty and the subsequent reconciliation of the polis? Did the Athenians truly abide by the oath to suppress memories of the preceding stasis and abandon their enmities for the sake of future harmony? ${ }^{3}$ The very fact that the history of the period survives - at times quite extensively - suggests that they did not. In that case, how did the Athenians move on from the unprecedented horror that was the reign of The Thirty to not only reoccupy the space in which their very democracy was dismantled twice over the past decade, but to do so in such a way that also reconciled their grievances of the past and alleviated their fears for the future?

\footnotetext{
${ }^{1}$ A "place of memory." I borrow this terminology from Pierre Nora, whose methodology I will explore in Chapter One.

${ }^{2}$ Assume BC for dating unless otherwise stated.

${ }^{3}$ I turn to Ober for a basic definition of stasis as "violent conflict among citizens within the civic space of the polis $(2005,172)$. Although a popular translation of this term is "civil war", Loraux is right to note that the translation is problematic given that it carries the baggage of Roman history which the Greek concept of stasis does not $(2002,107)$.
} 
In order to find answers, I turn to a holistic examination of the Archaic and Classical agora through both material culture and literary evidence, focusing on the sculptural monuments, inscriptions, and buildings with connections to Athenian conceptions of tyranny, democracy, and landscape. ${ }^{4}$ Although the space of the agora itself is by no means insignificant, the wealth of monuments found within it can be viewed as individual lieux de mémoire also. Consequently, what is most useful to understanding the memories associated with the agora proves to be an examination of the interaction between the space itself and its inhabitants both corporeal and inanimate - as they weave together a narrative of democracy and tyranny as reflected in the landscape. A narrative which is by no means objective reality but reflects the ways in which the Athenians chose to remember themselves - establishing stability through the illusion of continuity with the past, while simultaneously laying an ideological groundwork for the future of Athens. Thus, what enabled the success of the Athenian amnesty was not a spontaneous and manipulative forgetting but rather a careful and contrived episode of collective remembering already grounded in a long tradition of selective memory since the Archaic period.

Chapter One lays the foundations for these arguments by delving into the interdisciplinary methodology of memory studies. I examine the seminal works of three scholars - Maurice Halbwachs, Pierre Nora, and Paul Ricœur - to piece together a methodological approach which addresses the connections between collective memory, space, and constructions of identity. This combined methodology will be the one at work in my analysis of the Athenian Agora. Chapter Two will deal with the establishment of the agora as a civic space between the $6^{\text {th }}$ and $5^{\text {th }}$ centuries, during which the Athenians transformed monuments of patronage from the Peisistratid tyranny to symbols of an ancestral democracy: undoing recent memory and weaving together a narrative of democratic Athens instrumental to self-conceived Athenian identity. An identity which will become hotly contested with the rise of The Four Hundred in 411 and The Thirty in 403. Chapter Three will follow the reflections of this contestation upon the space of the agora to demonstrate that it was ultimately the reimagined Athenian narrative of democracy reflected in the monumentalisation of the agora as a lieu de mémoire which enabled

\footnotetext{
${ }^{4}$ This system of categorisation is more for the sake of practicality and structure than it is an attempt to provide insight into the nature of the examples, as it will become apparent through the course of the discussion that the Athenian Agora was a nebulous and multipurpose space - an identity which seeps into its frequenters and inhabitants both corporeal and inanimate alike.
} 
the reconciliation at the end of the decade. Therefore, the Athenian Amnesty is a phenomenon which owes its success to memory rather than to forgetting.

The study of memory is a relatively recent phenomenon, taking its shape as a discipline following the trauma of the Holocaust. This, in conjunction with the difficulty surrounding primary sources - particularly those pertaining to collective social history means that memory has not enjoyed much prominence in Classics. While Grethlein's 2010 The Greeks and their Past: Poetry, Oratory and History in the Fifth Century BCE is an excellent analysis of literary memory in ancient Athens which explores the boundary - or lack thereof - between the practice of history and memory, it concerns itself mainly with literature and literary memory. Steinbock's 2012 Social Memory in Athenian Public Discourse: Uses and Meanings of the Past is a careful and comprehensive application of social memory to Athenian history utilising a wide range of sources. However, Steinbock's scope is limited by his interest in the issue of Athenian public relations with other poleis Thebes in particular. Therefore, he often treats memory as a means to an end rather than a phenomenon in itself.

There have, however, been several works connecting the study of memory with the Athenian Amnesty in particular, no doubt owing to its relationship with amnesia. The most seminal of these works is Loraux's 1997 La cité divisée - L'oubli dans la mémoire d'Athènes, later translated into English as The Divided City in 2002. Through a series of essays surrounding memory, forgetting, democracy, and stasis, Loraux argues that the foundation of democratic unity is based in the loss of memory. She traces this claim back to mythical origins, starting with the violent contest between Athena and Poseidon, and moves through various episodes of reconciliatory forgetting against remembering as a destructive force citing the Furies as her main example. ${ }^{5}$ In doing so, she asserts that the reason for the success of the Athenian Amnesty was that it belonged to an ancient sense of forgetting, ever present in Athenian conceptions of self, reinforced in its double invocation of gods and curses which does not allow for the distinction between myth and reality. ${ }^{6}$ While her construction of the tradition of forgetting - and by extension, memory - is incredibly astute, Loraux's study leans heavily upon the conflation of myth and history. This is an unproblematic conclusion given the liminal space memory occupies between the two, but rather limits the range of her evidence. Moreover, the

\footnotetext{
${ }^{5}$ Loraux, (2002), 43, 157-158.

${ }^{6}$ Loraux, (2002), 66, 168.
} 
idea that forgetting serves as the foundation to democracy is unsatisfactory considering the often intrusive nature of memory - a conclusion needlessly shackled to the wording of the amnesty oath itself.

Wolpert's 2002 monograph Remembering Defeat: Civil War and Civic Memory in Ancient Athens picks up where Loraux left off and offers an isolated case study of The Thirty and the Athenian response to its aftermath. Wolpert offers two main arguments. First, that the violence of The Thirty was a systematic deconstruction of an entrenched democratic identity, with the goal of eliminating it so as to prepare the foundations for their own oppositional regime. ${ }^{7}$ Second, that this period of stasis and the democratic reoccupation was refigured in the civic discourse as an Athenian triumph despite the fact that many of the Athenian themselves had been complicit in the conflict. As opposed to a foundational forgetting, Wolpert instead, chooses to focus on the ways in which the stasis was remembered, manifesting itself mostly in the legal speeches of the $4^{\text {th }}$ century.

The only scholar whose focus successfully combines the questions of Athenian memory and identity with the archaeological evidence of space and monument in addition to literature and ritual is Julia Shear. ${ }^{8}$ She has written several works on the topic, ${ }^{9}$ the most prominent of which is her 2011 Polis and Revolution: Responding to Oligarchy in Classical Athens. In it, Shear offers a historical overview between 411 and $403 \mathrm{BC}$ with specific attention to detail paid to Athenian monumentalisation in the aftermath of the two oligarchies. In doing so, Shear argues that the ways in which Athenians chose to remember these episodes was instrumental to their ability to move forward as a cohesive polis while placing emphasis on the fact that both The Four Hundred and The Thirty made a considerable effort to change these narratives. The conclusion she arrives at echoes both Loraux and Wolpert, in that the Athenians considered themselves democrats triumphant over the tyrannies of The Four Hundred and The Thirty. These struggles were also refashioned almost as if they were external conflicts instead of instances of stasis, and that belief is what enabled the Athenians to reconcile. ${ }^{10}$ Shear's discussion is convincing and her influence on this thesis is undeniable. However, I hope to

\footnotetext{
${ }^{7}$ Wolpert, (2002), 22.

${ }^{8}$ Not to be confused with Leslie Shear Jr., whose work on the agora excavations also feature in this thesis.

${ }^{9}$ See Shear, J.L. (2007). "The Oath of Demophantos and the Politics of Athenian Identity," Shear, (2011), Polis and Revolution: Responding to Oligarchy in Classical Athens, and Shear, (2013), "Religion and the Polis: The Cult of the Tyrannicides at Athens."

${ }^{10}$ Shear, (2011), 103.
} 
place her argument in a broader context of continuity, with the attempts to remake and reclaim Athenian identity between 411 and 403 finding its precedent in the $6^{\text {th }}$ and $5^{\text {th }}$ centuries, providing further explanation for its effectiveness.

Before continuing, it is important to note three points of necessary caution regarding primary evidence. Firstly, although the advent of archaeology and the overdue acceptance of material evidence within Classics coincides nicely with an academic zeitgeist obsessed with memory and commemoration, it is important to remember that archaeological evidence is still incomplete, complex, and difficult to interpret. ${ }^{11}$ The mere survival of evidence itself is reliant on luck, and the existence of one remnant does not mean that it was not once shrouded in controversy, nor does the absence of another. ${ }^{12}$ Moreover, while a study of memory necessitates the examination of a wealthy "matrix" of sources from different media, instances of direct correlation between literary and material evidence in the ancient world remain exceedingly rare. ${ }^{13}$ This means that simply turning to material culture does not magically present a clear picture of Athenian collective memory, history, or identity, and nor should we expect it to. However, material evidence is able to corroborate possible insights into memory present within literary evidence and vice versa. More often than not, lieux de mémoire are also places of contested memory too important to ignore and therefore, worth examining despite their nebulous contributions as evidence. To give a basic example, the current restoration effort on the Athenian Akropolis clearly represents a contest between different cultural memories and narratives, of which a desire to return to ancient Athens triumphed and resulted in the dismantling of comparatively modern yet still historically significant structures such as the Frankish turret. ${ }^{14}$ Although the structures sacrificed for the sake of rebuilding an ancient Athenian Akropolis no longer exist physically, they are notable by their absence as this process itself is an artefact of Greek cultural history.

Therefore, while it is important to navigate around archaeological evidence and that which does not survive, the main focus of this thesis will be evidence which can be identified with some degree of certainty - often as a result of both archaeological and literary sources working in tandem. For instance, although buildings such as the Heliaia and the Prytaneion are named

\footnotetext{
11 Thompson, Wycherley, (1972), 24.

${ }^{12}$ Shear, (2011), 12.

13 Alcock, (2002), 2.

${ }^{14}$ Alonso, (1988), 49.
} 
within literature as key places of Athenian civic life related to both the transformation of democratic attitudes as well as the episode of stasis in particular, they are yet to be identified from excavation. While it may be tempting to speculate based on the survival of foundations such as the square structure found in the southwest, dated to the early agora and credited as the Heliaia by "process of elimination," these speculations alone are ultimately unsatisfactory and will not find themselves as examples. ${ }^{15}$

15 Thompson, Wycherley, (1972), 63. 


\section{Methodology and the City of Memory}

In recent scholarship the study of memory has enjoyed a rather privileged position, attracting attention from major cultural shifts following the Second World War. Not only did decades of bloodshed fuelled by nationalistic rhetoric shatter the illusion of monolithic "official" narratives, but the desire to memorialise the Holocaust led to an almost obsessive turn to memory. ${ }^{16}$ Memory flooded the landscape of scholarship, comparable to the ways in which ubiquitous commemorations at both a private and public level changed the landscape of Europe. Academics from across the humanities were suddenly interested in the phenomenon of memory. Some saw it as an organic and polyphonic antithesis necessary to rewrite the singular constructed histories that came before it, others as a new and long-neglected source to writing more diverse and inclusive histories. Despite the lack of consensus, the birth of Memory Studies as a new field, interdisciplinary by the nature of its inception, could not be ignored.

Thus, it is with the methodology of Memory Studies that I approach the Athenian Agora, a space haunted by the construction of narrative. Due to the depth of the field, I have decided to synthesize from three different scholars, each seminal to the study of memory while also acknowledging the contemporary scholarship they have influenced. First, I turn to Maurice Halbwachs" "collective memory" in defining the place and nature of memory within the Athenian polis. The aim of this is to contextualise the phenomenon of collective memory in Athens against a theoretical framework. Then, in order to evaluate and disentangle the scattering of evidence seemingly inhabited by memory, I will draw upon the work of Pierre Nora in categorising said evidence as lieux de mémoire (places of memory). Finally, I will examine Paul Ricœur's Memory, History, Forgetting to make sense of these traces of memory, particularly in the face of both forgetting and forgiveness - two concepts central to the philosopher's contribution to the study of memory.

\section{Seminal Scholars}

Inspired by Émile Durkheim, French sociologist Maurice Halbwachs first coined the term "collective memory" in the 1925 work Les Cadres Sociaux de la Mémoire which has since then

\footnotetext{
${ }^{16}$ Alcock, (2002), 24; Ricœur, (2000), 120.
} 
acted as the benchmark for Memory Studies. ${ }^{17}$ Although Halbwachs was unable to enjoy his rise to prominence as the father of the discipline due to his murder at Buchenwald in 1945, his remaining works on the topic were collated and published posthumously in La Mémoire Collective in $1950 .{ }^{18}$ Positing the idea that humans are social creatures whose actions are determined by their groupings, Halbwachs argues that the process of recollection and remembering does not belong to an individual, but is collective and enacted through relationships. ${ }^{19}$ For him, "our memories remain collective, and they are remembered by others, even though it is events in which we have been involved alone, and even though it is objects that we have seen only by ourselves... we always bring with us and bear in us a lot of people."20 Therefore, while "collective memory" is a rejection of the staunchly individualist notion of the memory and the self advanced by the Freudian school of psychology, it is at the same time, a recognition of the interdependence between personal and collective experience. ${ }^{21}$

This then, enables Halbwachs to explore phenomena such as the tendency for personal memories to resurface through the recollection of others, the presence of memories of events that one did not witness for themselves, and the ways in which a solitary individual interacts with unfamiliar experiences by drawing upon external memories. ${ }^{22}$ This phenomenon occurs through the recognition that all humans are capable of a shift in viewpoint, which for instance, manifests when individuals begin to see themselves as part of a collective. ${ }^{23}$ This means that in the same way, memory can undergo the same shift in viewpoint, enabling a person to view memories through the eyes of another, thereby blurring the lines between "true" memories which reflect experiences and events lived out by the individual, and "constructed" memories based not on an individual's empirical experience but the perspective of others. Ultimately, Halbwachs advances the notion that memory is a socially constructed phenomenon which fosters and is fostered by individual subjective experiences. An awareness of collective memory, then, acknowledges that the circumstances under which memories are formed, negotiated, contested, and transmitted are unique to different contexts, allowing for a more

\footnotetext{
${ }^{17}$ Dessingue, (2011), 169.

${ }^{18}$ Russell (2006) 792.

${ }^{19}$ Halbwachs, (1950), 23.

${ }^{20}$ Halbwachs (1950) 52.

${ }^{21}$ Freud stuff; Ricoeur, (2000), 127.

${ }^{22}$ Halbwachs, (1950), 24.

${ }^{23}$ Ricoeur, (2001), 121.
} 
nuanced examination of the ways in which different groups at different points in time perceived themselves, as well as the world around them. ${ }^{24}$

Although the idea of collective memory forms the foundations of Memory Studies as a discipline, it faces two major issues as an instrumental theory for the study of history. Firstly, Halbwachs did not intend for his writings to act as historical methodology, most apparent in his insistence that memory is living and constantly changing. Memory then, cannot be thought of in historical terms, with the past serving as its domain. Therefore, when memory crystallises from communication and interaction into tangible objects or records it no longer exists in the present but instead, becomes history. ${ }^{25}$ Consequently, collective memory in its conceptual sense cannot be expressed in terms of historical sources outside of living oral testimony, and therefore, would be impossible to study - especially in the context of antiquity. This then, leads to the second issue wherein despite its limitations, the use of the term collective memory has so often served studies of history that it no longer conforms to its original meaning. ${ }^{26}$ When anything can be classified and conflated as collective memory, it loses its significance and analytical power as a result.

In response to these issues, several popular alternatives to collective memory have emerged in recent scholarship. The most notable of these is social memory, a concept contemporary to collective memory and developed by art historian Aby Warburg borrowing the term first coined by Émile Durkheim in his 1923 Kreuzlinger lecture. ${ }^{27}$ In his work on primitive New Mexican belief systems, Warburg agreed with the sentiment of collective memory: that social groupings were united based on shared identities transmitted through memory. ${ }^{28}$ However, as an art historian, Warburg chose to focus on the visual sources of memory, arguing that it is shared social memories across generations which enables the meanings locked up in symbols to persist and be passed down. ${ }^{29}$ In doing so, an exploration of social memory became the evidence which allowed Warburg to decipher these symbols, but the symbols themselves also became the sources for social memory. Although initially eclipsed by Halbwachs, social memory has recently gained a revived interest following the publication of James Fentress and Chris

\footnotetext{
${ }^{24}$ Halbwachs, (1950), 30-33.

25 Assmann, Czaplicka, (1995), 128.

${ }^{26}$ Hutton, (2018), 296.

${ }^{27}$ Assmann, Czaplicka, (1995), 125.

${ }^{28}$ Confino, (1997), 139.

${ }^{29}$ Confino, (1997), 139.
} 
Wickham's 1992 work of the same name, gaining traction as an alternative paradigm. ${ }^{30}$ Similarly, Aleida and Jan Assmann's developments on cultural memory in the 1990's places Halbwachs' ephemeral collective memory into a historical framework, arguing that the invention of writing allows cultural memories to extend beyond their original time as crystallisations of memory. ${ }^{31}$ Moreover, that regardless of the terminology used, the outward expression of tradition and communication functioning in ways similar to individual memory deserves recognition as a phenomenon in and of itself subject to historical analysis. The paradigms of social and cultural memory then, enable the concept of collective memory to be conceived of in historical terms, offering sources from which these memories may be derived.

However, the most influential example of the intersection between history and memory studies as well as the theory most intimate with the Halbwachsian collective memory comes out of the works of Pierre Nora. $20^{\text {th }}$ century France was a serious period of self-reflection: in addition to the two World Wars when the nation was forced to reconsolidate the now shattered grandeur with which they wove their previous national history. ${ }^{32}$ French social upheavals of the 1970 s and 1980s marked by events such as the universal suffrage of 1962 and the end of the Algerian War in 1965 thrust the country into a period of identity redefinition. ${ }^{33}$ The unified image of the French nation had fallen, with marginalised voices coming to the forefront and the discipline of history, woven into the formative years of so many French citizens, chastised for contributing to narratives that had deluded the country and suppressed the more unsavoury elements of its past. ${ }^{34}$ This process then, ushered in an explosion of memory into French thought. ${ }^{35}$ Each social group within France that had previously been shunned by a singular history therefore, sought to find and reclaim their own traces of memory. ${ }^{36}$ For Nora, the patrimony which had previously been understood as the collective culture of the country and the soul of France was no longer the domain of a unified historical narrative, but had become synonymous with memory. ${ }^{37}$ Inspired by this, and the changes in the last century that had shaken not only France but the entirety of Europe, Nora sought to find a unitary model of

\footnotetext{
${ }^{30}$ Fentress, Wickham (1992).

${ }^{31}$ Assmann, (2011), 8.

${ }^{32}$ Hutton, (2018), 292-293; Siegel, (2002), 772-773.

${ }^{33}$ Nora, (2009), x.

${ }^{34}$ Nora, (2001), xi-xiii.

${ }^{35}$ Nora, (2001), $x$.

${ }^{36}$ Nora, (2001), xv.

${ }^{37}$ Nora, (2009), viii.
} 
examining history, memory, and identity, thus resulting in the inception of the lieu de mémoire. ${ }^{38}$

Building on Halbwachs' collective memory, Nora posits the idea that memory is a living force through which cultural communities imagine themselves. As a social phenomenon, memory is not monolithic but rather coloured by the mix of individuals that happen to constitute its groupings. ${ }^{39}$ Moreover, Nora too, subscribes to the idea that since memory is alive, it is bound to the present, which means that its survival is tied to commemorative practices such as celebrations, anniversaries, archives, and monuments. ${ }^{40}$ While memory is a warm living force, history is the cold reconstruction of the past - a chasm which became most apparent in interwar France when the glory of France was the least convincing and the process of remembering became most self-aware and introspective. ${ }^{41}$ For Nora, it is impossible for modern communities to live in the presence of memory because there is no longer a need for societies to maintain rituals and traditions which pass values on from one generation to another, since the clinical pursuit of history has taken its place. ${ }^{42}$ Instead, they create vestiges of the past through a desire to remember, and these vestiges - although in a sense artificial replacements of the real, lived memories - are the closest substitute for memory that modernity can afford, thus earning the name of the "lieux de mémoire". ${ }^{43}$

Therefore, what started as an experimental project to revisit French places which may trigger the memories of a bygone time eventually became a compendium of lieux de mémoire through Nora's series of volumes titled Rethinking France. Rethinking France served almost as an archaeological rediscovery of memory, preserved only as lieux de mémoire. As his explorations into memory became more comprehensive, so too did the definition of lieux de mémoire have to service its growing scope. In short, lieux de mémoire are the places - both physical and metaphorical - where memory has crystallised, much like shells left on a shore after the tide of living memory has receded. ${ }^{44}$ These so-called "places" however, can range within a broad spectrum, from places and monuments to the tropes of public discourse and the memories of prolific individuals, echoing Assmann's conceptualisation of objects which occupy a liminal

\footnotetext{
${ }^{38}$ Nora, (2001), vii.

${ }^{39}$ Nora, (1989), 8.

${ }^{40}$ Nora, (1989), 7-8.

${ }^{41}$ Nora, (2001), $\mathrm{x}$.

${ }^{42}$ Assmann, (2011), 7.

${ }^{43}$ Nora, (1989), 1-8.

${ }^{44}$ Nora, (1989), 7.
} 
space between objectification and memory, for they signify meanings and purposes outside of their practical purpose. ${ }^{45}$ Ultimately, the inception of the lieux de mémoire was an attempt by Nora to understand the function of collective memory, transforming it from a philosophical treatise in the abstract into a workable historical method. These lieux de mémoire are thus able to quantify as sources of collective memory the physical symbols and spaces of the art historian or the archaeologist just as well as inscriptions for the social historian or even texts for the philologist.

This perspective, although helpful as a paradigm for categorising and thinking about sources, is nevertheless flawed in its romanticising of memory as well as the distant past. Memory, despite its being more cognitive and psychological than intellectual is nevertheless still a reconstruction of the past - subject to both conscious and subconscious manipulation and forgetting. Although it is easier to think of the downward manipulation of history through the erasure of minority narratives, the same manipulation can be used through memory to join together disparate individuals in the very communities that Nora lauds. ${ }^{46}$ Examples of this manifest themselves within responses to Nora's work, as its most sceptical critics argue that even Nora tactfully neglects the darkest corners of French history, such as the fact that its modern triumphs are built atop foundations laid during a period of overzealous colonial ambitions. ${ }^{47}$ It is simply impossible to encompass everything within a study of memory. Moreover, the chasm Nora claims between history and memory, with memory as the superior vehicle upon which the past is carried, is once again a romanticised notion of memory decidedly bound to its French context. For instance, Nora's claim that ancient societies did not produce lieux de mémoire but rather, milieux de mémoire (environments of memory), since they were still bound by tradition and had no need to create inorganically sterile remnants of the past, is problematic. ${ }^{48}$ Memory, as well as attempts to modify memory and recreate the illusion of a unified narrative from which societies could derive their identities were ubiquitous in both Ancient Greece and Rome.

It is at this point then that we must turn Ricœur's work on memory. A French philosopher, Ricœur follows in the footsteps of Halbwachs and Nora in exploring the relationship between

\footnotetext{
45 Assmann, (2011), 7.

${ }^{46}$ Barash, (2016), 81-82.

${ }^{47}$ Barash, (2016), 81-82.

${ }^{48}$ Nora, (1989), 1.
} 
history and memory in a world following the Holocaust. Published in 2000, Ricœur's History, Memory, Forgetting presents a comprehensive history of memory studies as the foundation for an analysis of memory itself, as well as memory's relationships to history, politics, psychology, and identity. In it, Ricœur proposes that memory represents the intersection between two axes: the horizontal bond humans share of living together in a contemporary time, and the vertical bond through which the "authority of the ancients" is transmitted. ${ }^{49}$ Memory therefore, constructs the identities of both individuals and collectives, with the authority of the antiquated vertical tradition feeding continuity, and the illusion of continuity, into a living horizontal present. It is through this intersection, Ricœur argues, that memory can be abused. Similar to history, memory - particularly collective memory - is the representation of an authoritative narrative subject to manipulation, often in order to serve political purposes through the change, formation, or destruction of collective identities salient to the values of the current leadership. ${ }^{50}$ In doing so, memory effectively smooths over what Ricœur calls the "salutary fragilities" of identity, making synonymous the identity of a group and the ideology of a dominant power. ${ }^{51}$ Where it differs most from history is not its supposed subjectivity but rather, its simultaneity, since the protagonists of memory-narrative are written contemporary to their existence and actions. This then, generates a symbiotic living relationship whereby the actors contribute to the narrative while the narrative itself influences the actors. ${ }^{52}$

Additionally, Ricœur's philosophy is particularly useful due to the attention it gives to both forgetting and forgiving. As the title of his monograph suggests, Ricœur affords the phenomenon of forgetting the respect it deserves not only as the flipside of memory but an issue in its own right. Initially Ricœur draws a distinction between passive and active forms of memory, suggesting that the work of memory is spontaneous while the duty of memory is represented by an active desire to recall and the language of memory spoken in the imperative mood. ${ }^{53}$ Likewise, forgetting can be both passive and active, but occupies also a liminal space between the two through apathy and avoidance. The desire to not know something is active, and from it spawns passive ignorance. ${ }^{54}$ Moreover, collective forgetting is arguably more linked to the individual than collective memory, as true forgetting representing a loss of

\footnotetext{
${ }^{49}$ Ricœur, (2004), 60.

${ }^{50}$ Ricœur, (2004), 85.

${ }^{51}$ Ricœur, (2004), 82.

${ }^{52}$ Ricœur, (2004), 85.

${ }^{53}$ Ricœur, (2004), 87.

${ }^{54}$ Ricœur, (2004), 432-434.
} 
knowledge for the individual depends largely on the collectives to which they belong experiencing the same loss in order to eliminate the reminders of the forgotten. ${ }^{55}$ Therefore, collective forgetting is just as, if not more, susceptible to institutional and legislative manipulation. For Ricœur, the pinnacle of this manipulation is amnesty, which formulates a façade of forgiving without doing its work. Instead, collective forgetting, through the politicisation of memory, ignores and denies even familial murder and in turn, sustains conflict under the pretext of closure and progress. ${ }^{56}$

To simplify, the theories of the three scholars can be combined into a mechanism for understanding the relationships between memory, identity, and space. The instinct to remember is human, in that we seek continuity with the past in order to find comfort in the continuation of life after death. ${ }^{57}$ It is this base instinct which lends memory a legitimising and authoritative power. If memories are bound up in spaces and monuments, then these lieux de mémoire are physical representations of the force of memory - connecting together past, present, and future. The physical permanence of objects from another time bring the past into the present through their presence. While the object itself carries meanings from a bygone time, it is also susceptible to the manipulations of the present ideologies, thus enabling it to change in meaning or begin to represent something else entirely. An object itself can also be modified or destroyed. Finally, in an almost cyclical nature, a lieu de mémoire is a promise for the future, in that the physicality of an object surviving from the past implies that it will continue surviving into the present - signifying continuity. Therefore, it is the force of these spaces and objects which are instrumental to constructions of collective identity, whether it be self-conceived or the result of external force. Applying this methodology to Athens and examining the transformations of the agora through the lens of memory can thus, shed insight on the ways in which the collective chose to remember, and thereby, chose to fashion their own identities.

\section{Why Athens?}

The study of memory has always been interlinked with Classics, with Aristotle's Poetics - and at times, Plato's Theatetus - being recognised as the inceptive sources on memory by most

\footnotetext{
55 Ricœur, (2004), 443-444.

${ }^{56}$ Ricœur, (2004), 87.

${ }^{57}$ Crane, (1997), 1373; Finley, (1971), 29.
} 
scholars attempting to document its history. ${ }^{58}$ Not only that, but the study of Athenian social history itself is especially well suited to a memory-based examination by nature of its sources. Since the sources we have were mainly written by a small elite, Athenian social historians must look beyond surviving texts to other traces of evidence in order to reconstruct a comprehensive and inclusive picture of the Greek past. Therefore, social historians turn to epigraphical and archaeological evidence. What these traces of the mundane share in common is their occupation of space and interaction with the world around them on a physical level, and therefore, their ability to serve as lieux de mémoire. In the world of archaeology, the metaphor of seashells leftover from a receding tide takes a much more literal presence as artefacts leftover with each layer of uncovered earth. Beyond this metaphorical sense, Steinbock identifies two virtues of employing memory studies applicable solely to studies of the ancient world. Firstly, doing so allows for a lateral examination of a variety of sources, encompassing material culture as well as literature and historical writings. ${ }^{59}$ Secondly, Steinbock argues that in examining these sources collectively under the framework of memory, one is able to gain a more nuanced appreciation of their significations since it enables them to look beyond the restrictions of textual analysis. ${ }^{60}$ Of course, it would be impossible to fully reconstruct an accurate model for the collective memory that lived within the public sphere of the Athenian world at any given point in antiquity, but to ignore the wealth of evidence that is available on the basis of an unachievable standard of completionism would be daft.

Furthermore, Classical Athens as a polis was a space steeped in memory driven by the prevalence of her collective identity, evident in both grandiose and small gestures of monumentalisation present throughout her public spaces. These physical manifestations of memory were subject to constant renegotiation parallel to Halbwachs' socially constructed memories: statues could be moved, monuments could be transformed, and inscriptions could be erased to make room for new discourse within the same space. ${ }^{61}$ Erasure was, therefore, a physical and political act in Athens, and what some may perceive to be purely aesthetic changes were, as Ma observes, meaningful choices made by people who were well aware of their own roles in the construction of their collective identity. ${ }^{62}$ In addition to material monuments, Athenian rhetoric constantly placed heavy emphasis upon an illustrious ancestry, with

\footnotetext{
${ }^{58}$ Dessingue, (2011), 170; Ricœur, (2004), 8-9.

${ }^{59}$ Steinbock, (2013), 5.

${ }^{60}$ Steinbock, (2013), 5.

${ }^{61} \mathrm{Ma},(2009), 252$.

${ }^{62} \mathrm{Ma},(2009), 252-253$.
} 
decisions being made in accordance to the past. For instance, both The Four Hundred oligarchs in the coup of 411BC and democrats following the amnesty appealed to the patrios politeia (ancestral constitution) in their re-establishment of legislation, evoking the authority of the past through memory yet negotiating its meaning to suit the present. ${ }^{63}$ All this was compounded by the Athenian notion of the collective, as the life of the citizen was defined by his various associations - from his place in the deme to his enfranchisement in the polis. ${ }^{64}$ Isolation of the individual was then, an alien concept to the Athenian citizen, who continuously existed within shared spaces. ${ }^{65}$ As a result, the Halbwachsian conception of memory is perhaps, more suited to examine such an environment than to any other.

Moreover, the Athenian Agora was an especially unique place in terms of its contributions to Athenian civic identity. Vlassopoulos makes the argument that the Athenian Agora as a place in itself would have been unique due to the phenomenon that is democratic Athens. Noting the vast geography of Attica, Vlassopoulos observes that Athens, more than any of its contemporaries, was an imagined community in which a large majority of its citizens could not interact with each other daily. ${ }^{66}$ Furthermore, because Athens was the meeting place of not only Attica but the Black Sea, the Eastern Mediterranean, and Sicily due to the prominence of the Piraeus harbour, it became a melting pot of diverse individuals, especially considering her economic dependence on the import of not only goods, but skilled maritime labour as well. ${ }^{67}$ From the apex of the Classical period onwards, Dougherty suggests that Athens even attracted a wealth of tourists. ${ }^{68}$ Thus, the issue of Athenian identity was complicated, and questions surrounding citizenship in particular found themselves at the forefront of discourse. The Old Oligarch famously insults Athenians on the basis of their inability to be distinguished from slaves (Constitution of Athens, 1.10).

However, since the integration of diverse individuals is an important part of the foundations comprising Athenian success, Vlassopoulos argues that the Athenians practiced a necessary degree of tolerance to non-citizens partly expressed through their use of space. ${ }^{69}$ In particular, he identifies the Athenian Agora as a "free space" in which people of different backgrounds

\footnotetext{
${ }^{63}$ Shear, (2011), 16.

${ }^{64}$ Alcock, (2002), 15.

65 This idea is asserted in Ismard's 2010 monograph La cité des réseaux.

${ }^{66}$ Vlassopoulos, (2007), 35-37.

${ }^{67}$ Vlassopoulos, (2007), 37.

${ }^{68} \mathrm{Ma},(2009), 394$.

${ }^{69}$ Vlassopoulos, (2007), 50.
} 
could come together and create shared experiences and interactions, thus strengthening and enriching their collective identity. ${ }^{70}$ These free spaces of deliberation, as Evans and Boyte note, is the "primary means through which democratic visions and capacities are nourished" through "connect(ing) participants to larger patterns of decision making, social life, and institutional practice." ${ }^{71}$ Therefore, the Athenian Agora was essential to the existence of a collective Athenian identity, serving as the heart of the imagined community which united citizens and non-citizens alike across Attica and the Mediterranean. ${ }^{72}$ The enfranchisement of the poor was key to the formation of this free space: the disgruntled views both the Old Oligarch and Lysias express at the lack of definition between a low level labourer and a metic or slave reflects the degree of diversity within the agora, and the inability for individuals occupying that space to discriminate against each other. ${ }^{73}$ Thus, based on the shared experiences of a shared space, the Athenian democracy adopted a unique and robust collective identity necessary for its continued operation.

In continuously channelling memory, Athenians embodied the essence of the collective memory paradigm, participating in a social and dynamic process in which memories constructed in the present lead to constant redefinitions of self-identification. This process then, generated what Steinbock terms the "Athenian Master Narrative" - a medium which expressed the fluid and malleable image which the Athenians had of their past, often adapting to suit the purposes of the time. ${ }^{74}$ Steinbock argues that although Classical historians viewed the Athenian Master Narrative in terms of its social significance and ideological function by identifying the outstanding events within it, they often dismissed the overall manifestation of memory within the civil discourse of the polis as unsubstantiated evidence at best and falsehoods hidden in propaganda at worst. ${ }^{75}$ However, to do so would be to take for granted the importance of memory as a key form of political capital, acting as crucial currency in the process of decision making and to subsequently, shun its value as a resource in the study of historical analysis. ${ }^{76}$

\footnotetext{
${ }^{70}$ Vlassopoulos, (2007), 32, 38.

71 Evans, Boyte, (1992), ix: "Free space is found in settings which combine strong communal ties wit larger public relationships and aspects. This public dimension involves a mix of people and perspectives beyond one's immediate personal ties, and also entails norms of egalitarian exchange, debate, dissent, and openness."

${ }^{72}$ Echoing Camp's sentiment that the Agora was the heart of Attica, and Attica was the heart of the ancient Greek world.

${ }^{73}$ Vlassopoulos, (2007), 33-34.

${ }^{74}$ Steinbock, (2013), 20.

75 Steinbock, (2013), v.

${ }^{76}$ Steinbock, (2013), v.
} 
One also cannot discuss the study of memory in the context of Athens without touching upon the Athenian Amnesty. On a surface level, it seems almost obvious to examine the Athenian Amnesty through the lens of memory as its language serves as the negotiator of reconciliation. It is no coincidence that the English term "amnesty" recalls amnesia, a forgetting between two parties of ills that had transpired between them, fittingly derived from oath of me mnesikakein sworn individually by the Athenian citizenry in 403 . Therefore, the implication of the oath from a purely linguistic perspective is that the presence of peace necessitates the absence of memory. This is not simply forgetting, a passive phenomenon reflecting the failure of memory - the only form of failure with which humans are familiar and comfortable - but rather, the deliberate effort to not recall. ${ }^{77}$ In doing so lies a paradox, to acknowledge that one is not recalling a memory is to recognise that memory's existence in the first place, for true forgetting is the absence of memory and the total inability to recognise its presence. ${ }^{78}$ As Ricoeur articulates "recognising a memory is finding it again. And finding it again is assuming that it is in principle available if not accessible" ${ }^{79}$ The oath to not recall is therefore, an oath to the preservation of a memory which cannot be acknowledged. Even in an instance where an oath to not recall can effectively trigger a process of forgetting, Ricœur suggests drawing on Freudian psychological analysis, that the trauma of violent stasis cannot be easily erased. In lieu of the forgotten or repressed trauma arises other symptoms, and certain seemingly arbitrary triggers can cause episodes of traumatic memory to return: signifying the permanence of its presence even in instances where it is inaccessible. ${ }^{80}$

This process is further complicated by two factors: the form of the oath which the amnesty takes and its collective nature. Firstly, the fact that the Athenians' clause of reconciliation was not a piece of legislation but rather an oath sworn by the citizen body may pose questions of memory in itself. The oath was unlikely to have been inscribed and displayed but rather, relied on the swearer's subservience to the threat of divine vengeance and their promise to not break it. ${ }^{81}$ Thus, the keeping of an oath relies on the memory of the swearer - of both the oath itself and the consequence of breaching it. The latter, divine vengeance in name but in practice more likely a violation of social norms, is again, operated through memory as the continuity of such norms and religious beliefs relies on the transmission of collective memory through

\footnotetext{
77 Ricœur, (2004), 443.

${ }^{78}$ Ricœur, (2000), 100.

${ }^{79}$ Ricœur, (2000), 433.

${ }^{80}$ Ricœur, (2000), 445.

${ }^{81}$ Rhodes, (2007), 34.
} 
generations. Secondly, although the swearing of the amnesty oath was done through individuals, the goal of doing so was ultimately to mediate conflict within a collective. An individual's swearing of the same oath as their peers to form a collective much resembles the process of collective memory, in that diverse individual memories of the same event combine together to form a polyphonic collective narrative. ${ }^{82}$ Collective memory then, haunts the phenomenon of the amnesty, conspicuous in its forced absence as well as the echoes of its mechanics.

Memory theory then, opens up two promising avenues of analysis. The language employed by the Athenians provides a clear imperative for contemporary scholars to examine the event as the domain of not only history, but also memory. In doing so, new insights may be unlocked regarding the efficacy of the Athenian Amnesty, its qualities as a social event, and its subsequent ripples within Athenian society. Moreover, these insights may lead to new discoveries about the general nature of amnesty, and the role which collective memory plays in facilitating peace after conflict. More importantly, the fact that Athenians chose to employ the language of memory themselves indicates that they viewed amnesty as a function of memory. This in itself, reveals avenues for the study of collective memory within bygone societies. If the Athenians recognised the social clout of memory, and actively utilised it as a functional mechanism within their politics, then there is perhaps even more reason to apply memory studies to the ancient world.

Nora's lieux de mémoire paradigm also works well to complement a study of the Athenian amnesty. Within historical narratives, the details surrounding the swearing of the amnesty oath are often brief or conflicting. The author of the Athenian Constitution gives the most detailed account of the oath being sworn. He claims that it was one of the terms for the oligarchs who wished to remain in Athens as opposed to moving to Eleusis for political sanctuary during the initial reconciliation in $403 \mathrm{BC}$, with a reaffirmation of this oath being taken after the slaughter of the Eleusinians in 401/400 BC (39). ${ }^{83}$ However, Xenophon attributes the oath of $m e$ mnesikakein as an event which followed in the aftermath of Eleusis (2.4.38). Dionysius of Halicarnassus is vague in his description, claiming that the oath occurred after the restoration of democracy without clarification on the event in question, and Diodoros seems to reject these

\footnotetext{
${ }^{82}$ Shear, (2011), 226.

${ }^{83}$ Walbank, (1982), 95.
} 
events altogether, claiming that the oath was sworn after the return of the exiles which occurred in 401/400 BC (14.32-33). ${ }^{84}$ In addition to the confusion, historical evidence from antiquity is more susceptible to the illusion of a unified narrative by nature. Due to the limited survival of ancient sources, we must be even more judicious in their evaluation, particularly regarding the passage of time between historical accounts and the lack of citation as a practice. For instance, Justin's history of the oath being sworn after the fall of Eleusis seems to corroborate that of Xenophon (5.10.11), yet as a historian working during the Roman Empire it is most probable that Xenophon had simply been one of his sources. ${ }^{85}$ We cannot privilege a source simply because of its origins in antiquity.

It is in instances where ancient historians fail that we must turn to social history, a discipline reminiscent of Nora's conception of memory. Outside of historical accounts, traces of the amnesty can be found in places, inscriptions, and orations - the latter of which serves as one of the most prolific sources of evidence for contemporary historians. The fact that any member of the former oligarchy wanting to run for office under the reformed democracy had to undergo a legal audit meant that the subject of the amnesty itself became a contested issue in these speeches. Not only that, but external to these audits the question of character in the immediate aftermath of Athenian stasis became intimately linked with the prosecution and defence for even issues totally unrelated to the conflict itself. ${ }^{86}$ This then, has led details of the amnesty to be illuminated in oration - for instance, the only account of the words spoken as part of the amnesty oath taken by the people, the jurors, and the senators exists within Andokides' On the Mysteries (1.95). ${ }^{87}$ Although Dorjahn, among others, is correct in noting that orators are less interested in historical fact than the reputation of their clients, ${ }^{88}$ this does not discredit the usefulness of speeches as a source. The very fact that details of the stasis feature so prolifically in a public setting within these speeches is helpful in defining the nature and limitations of the amnesty. Moreover, the carefully crafted individuals and narratives designed to sway public opinion as well as the emotional thrust of the arguments better illuminate prevalent attitudes surrounding the aftermath of stasis and how the Athenians dealt with them - an indispensable element of the amnesty's historically renowned success. Finally, even if an orator is inclined to be dishonest about individual actions and achievements, they are not likely to twist the

\footnotetext{
${ }^{84}$ Krentz, (1982), 104.

${ }^{85}$ Krentz, (1982), 104.

${ }^{86}$ For further discussion on this topic, see Chapter Three.

${ }^{87}$ Dorjahn, (1946), 12.

${ }^{88}$ Dorjahn, (1946), 31.
} 
technical details of the amnesty and the process of the oath-taking: it would be almost impossible to fool the Athenians who had all shared the same experience. In fact, an honest recollection of a shared memory would be more likely, as it would better appeal to the empathy of the jurors while reinforcing the credibility of the speaker.

Within Memory, History, Forgetting, Ricœur argues that amnesty is, at its core, a heinous abuse of memory. Noting the phonetic and semantic differences between "amnesty" and "amnesia", the French philosopher deems amnesty the politicisation of both memory and forgetting which erases the physical and social traces of trauma and guilt in order to build reconciliation upon the foundations of a false identity. ${ }^{89}$ In doing so, Ricœur accuses the Athenian Amnesty of exemplifying such abuse, wherein through the oath of me mnesikakein the Athenians hid the reality of their stasis and constructed for themselves an Athens historically devoid of internal conflict. ${ }^{90}$ Moreover, for Ricœur, the act of oath taking appeals to a religious facet of Athenian life, as if the Athenians had called upon a religious figure for the strength of will needed to forget. ${ }^{91}$ This "conspiracy" between oath and forgetting, as he calls it, is unacceptable, and leaves no room for genuine reconciliation. ${ }^{92}$

At the outset, Ricœur's sentiment may put his theory at odds with the Athenian Amnesty. However, a closer examination of his assessment suggests that Ricœur was unaware of the ways in which the amnesty unfolded in practice. Although its name and procedure may suggest that the Athenians simply ejected their experiences of stasis from a national narrative postreconciliation, and this seems to be the view Ricœur adopts, the very fact that the Athenians erected several monuments in the years following the stasis to commemorate the democratic victory - three of which being decrees awarding members of the resistance - suggests otherwise. ${ }^{93}$ In addition to public physical displays, the aforementioned ubiquity of the stasis within spoken discourse at the very least point to the fact that the Athenians acknowledged the conflict itself. On a more basic level, the fact that the stasis and subsequent amnesty did not escape the testimonies of several historians seem to be proof in itself that the event was not obliterated from memory in the dramatic fashion Ricœur suggests to his readers.

\footnotetext{
${ }^{89}$ Ricœur, (2000), 453.

${ }^{90}$ Ricœur, (2000), 453.

${ }^{91}$ Ricœur, (2000), 488.

92 Ricœur, (2000), 501.

${ }^{93}$ For a more comprehensive discussion of these monuments - two of which were found in the agora - see Chapter Three.
} 
Ricœur's rather Christian idealisation of Athenian oath-taking conveniently in-tune to his own conception of forgiveness is in itself problematic. Athenian oaths, while they did include the arbitration of a religious party, were not prayers for strength or willpower, but more akin to curses with the deterrent of divine punishment should they be broken. Furthermore, Carawan argues that the true forgiveness which Ricœur speaks of is in itself is a post-Christian cultural construction, so to superimpose a similar phenomenon upon the Greeks is not only problematic but anachronistic. ${ }^{94}$ However, what the philosopher leaves out of his assessment of the Athenian Amnesty, perhaps due to his misunderstanding of its nature as literal, is the extent of trauma the Athenians were left to reconcile. Within Ricoeur's monograph - among a multitude of others in memory studies - the Holocaust often returns as a point of reference: it is an unfathomably traumatic, unforgivable event, causing multi-faceted levels of complicity and guilt, and for these reasons, is over-saturated in commemoration due to the fear of its forgetting and the possibility of its repeating. ${ }^{95}$ In many ways, the same argument can be made for the reign of The Thirty. Although on a comparably smaller scale, the trauma inflicted upon Athens through the confiscation, displacement, and executions of The Thirty has often been emphasized as unprecedented atrocity for the Athenian populace only exacerbated by their recent loss in the Peloponnesian War. ${ }^{96}$ Yet while the Holocaust is the focal point of collective memory studies, the Athenian Amnesty remains somewhat forgotten. If contemporary scholars, using a memory-based investigation of post-war Germany can yield compelling results of evidence linking the ways in which collective memories of recent trauma affect political decision making, then surely similar connections can be made for $5^{\text {th }}$ century Athens. ${ }^{97}$

\footnotetext{
94 Carawan, (2013), 7.

95 Alcock, (2002), 24.

96 Wolpert, (2002), 126-127.

97 Young, (1993), xi.
} 


\section{The Athenian Agora and its Monuments: from the Peisistratid Tyranny to the end of the $5^{\text {th }}$ Century}

The Athenian Agora is a place of memory containing several monuments which can be viewed independently or in conjunction with the space they inhabit. This is the result of a rich and at times, complicated history intimately linked with the development of Athenian political attitudes. Although Wycherley claims that the agora was so important to Greek life that the word remains untranslatable and few scholars would disagree with its importance to Athens or any Greek polis - there is nothing inherently special about its formation. ${ }^{98}$ In practical terms, an agora was simply an open square reserved for whatever activity required the space - mercantile, religious, or civic. While the multipurpose nature of an agora renders the common translation of "marketplace" unsatisfactorily simple, its generic nature does not encourage a more specific definition either. Yet, the Athenian Agora remains one of the most prolific places in Ancient Greece in no small part due to its ties to Athenian identity. Therefore, the aim of this chapter is to explore the transformation of an unremarkable place into the heart of democratic Athens through an analysis of select monuments and buildings from their Peisistratid origins to the last decade of the $5^{\text {th }}$ century. As Athens underwent ideological shifts and struggles, so too did the landscape correspond to these contestations. The existence of these contests, in and of themselves, is emblematic of the power of space and the desire to wield it.

\section{Space, Place, and Monument}

That the Athenian democracy is so intrinsically linked to the agora reflects the fact that identity, as an extension of memory, is connected both metaphorically and metonymically to place. ${ }^{99}$ The idea that memory is localised is not a recent innovation that began with Halbwachs and Nora but a longstanding facet of the ars memoriae (art of memory) which Cicero attributes to Simonides, who suggested tying memories to specific places for ease of recollection (de Oratore, 2.86.351-354). ${ }^{100}$ Weinrich makes a more poetic comparison, identifying the river

\footnotetext{
98 Wycherley, (1962), 50.

${ }^{99}$ Basso, (1996), 11.

${ }^{100}$ Within Cicero's anecdote Simonides draws inspiration for his idea from an incident at the house of Scopas the Thessalian. When Scopas' house had collapsed during a symposium, Simonides as the only survivor was able to identify the mangled bodies for burial only on what place they had occupied during the night's festivities. This technique is widely known today as the "Memory Palace", most recently popularised by BBC's 2010 television adaptation of Sherlock.
} 
lethe (forgetting) as the stream which wears down on the contours of memory. ${ }^{101}$ On a psychological level, memory finds its connection to place as recollection functions best with simple and concrete occurrences and associations such as places, images, objects, and gestures. ${ }^{102}$ Moreover, these simple associations fulfill the requirements of providing a sense of personal identity and continuity alongside maintaining the memories themselves.

At this point, a definition of the terms "place" and "monument" may prove useful. In simple terms, "space" is the naturally occurring world, undefined in its capacity as well as its form. "Place" on the other hand, is a human construction enabled through the choice to interact with or inhabit certain spaces, during which the space absorbs and adopts for itself memories, values, and identities through a process Basso dubs "interanimation." 103 In simple terms, to interanimate a space would be imbue it with meaning through practices such as drawing borders or naming. Although it is a common anthropological assumption that the place remains passive, acting as a blank tablet onto which the particularities and histories of a culture come to be inscribed, that is not the case. ${ }^{104}$ Rather, the relationship is reciprocal, with a place "living" in its people and visitors just as much as it is inhabited by them. ${ }^{105}$ It is also important to remember that the critical apparatus with which humans perceive the world around them is the human body operating through senses, so a place's texture, sound, smell, and climate all become inseparable from its abstract associations. ${ }^{106}$ Thus, it is not difficult to conceive of these places as places of memory, where there exists the memories of a place which belong to an individual or collective, as well as the memories belonging to the place itself. ${ }^{107}$

Monuments operate like places in that they are not passive objects serving only the purpose with which they were prescribed by those who erected them. A monument in a vacuum is merely an object, and objects in themselves are amnesiac without the necessary and continued human interaction which perpetuates what is bound up within them. ${ }^{108}$ This interaction can take several forms, of which ritual and inscription are most relevant to ancient Athens. Repeated rituals surrounding a monument reinforcing both its associated meaning and the events that

\footnotetext{
${ }^{101}$ Weinrich, (1997), 6.

102 Nora, (1989), 8.

103 Geetz, (1996), 260.

${ }^{104}$ Meyer, (2013), 456.

105 Geetz, (1996), 260; Ma, (2009), 252.

106 Casey, (1996), 19.

${ }^{107}$ Casey, (1996), 25.

108 Young, (1993), ix, xiii.
} 
brought it into being act as what Ricœur calls "the most wildly desperate act(s) to resist forgetfulness." 109 These rituals may be on a scale as personal as mourning at a loved one's gravestone, or as public as the dawn service commemorating the war dead. On the other hand, inscription serves as an extension of ritual, linking together different temporalities by attributing a specific meaning to the monument and enabling even a stranger to interact with it through reading - a form of ritual in itself. ${ }^{110}$ For Ma, this means that an inscribed monument is particularly effective at constructing and manipulating memories and truths, thus perpetuating a collective memory and, by extension of that, a collective identity representative of an ideal citizen. ${ }^{111}$ Therefore, the fact that evidence survives of recorded meanings attributed to specific monuments suggests that there is no reason to think of the polis as Nora's unproblematic and unthinking ideal where memory had been experienced organically and there was no use for the lieux de mémoire. ${ }^{112}$

To complicate matters further, neither ritual nor inscription guarantee the permanence of the monument's original intended meaning. Inscriptions can be erased, rituals can be modified or lost completely, and the monuments themselves can perish. There is then, a contrast between the fluidity of a monument as a place of memory, and the permanence and stability of an actual place based on land. ${ }^{113}$ As Boardman articulates, any substantial structures created in periods of greater prosperity act as permanent reminders of the past, and will be monumentalised again by later generations to service unrelated, and sometimes entirely fictional, narratives. ${ }^{114}$ For instance, a grave dating to the Mycenaean era on the Akropolis was later commemorated as the grave of Kekrops, inspiring the inception of his heroic cult and the Karyatid porch to be built around it. ${ }^{115}$ The original identity of the inhumed individual was likely as opaque to the Classical Athenians as it is to us, yet the survival of the tomb itself and the air of vague importance that surrounds any monument enabled its subsequent associations. This, in turn, provided the Athenians with a sense of continuity - a resource for both survival and progress - based on the "newfound" ancient authority of the place - something with greater permanence than even the tomb's original purpose, seeing as the Erechtheion still stands today. Alcock's

\footnotetext{
${ }^{109}$ Ricœur, (2002), 44.

110 Shear, (2011), 160-161.

${ }^{111} \mathrm{Ma}$, (2009), 250.

112 Nora, (1989), 7. The Athenians themselves are perhaps most guilty of this, due to their epigraphic obsession discussed in Chapter Three.

113 Young, (1993), 10.

114 Boardman, (2002), 19.

${ }^{115}$ Rubel, Vickers, (2014), 118.
} 
definition of "monument" simplifies this rather complicated set of meanings: "that is, places, structures, or objects deliberately designed, or later agreed, to provoke memories."116

\section{Monuments}

The changes in the Athenian Agora as a place were bound in the changes made to its monuments as they often took on meanings of their own. Therefore, it is important to examine them individually and in relation to each other to better define the holistic transformations of the agora as a place. In order to better understand the relationship of place to the narrative of Athenian democracy, I have selected several monuments which either evolved according to, or were formed as a result of, Athenian responses to their shifting ideology from the Peisistratid formation of the agora to the apex of the Classical agora as a civic space. They are categorised by function in terms of "sculptures" and "buildings." However, as the course of the chapter should demonstrate, it is often pointless to distinguish between types of "monuments" as their differences are arbitrary - just as there is no overarching purpose to the agora itself. Thus, these distinctions should be taken not as technical definitions, but as simple signposts for the sake of the reader. ${ }^{117}$ Furthermore, given that public inscriptions did not gain prominence in the agora until after the reign of The Four Hundred, they will be discussed in the following chapter.

It is also important to note the origins of Athenian monuments in the agora. Until the end of the $6^{\text {th }}$ century, most of the architecture in Athens and Attica were sponsored by prominent families as a result of their contest for power through ostentatious displays of wealth and patronage. ${ }^{118}$ The very idea of state sponsored buildings and monuments, something that would become commonplace in Athens during the Classical period and a facet of her democratic pride, was not introduced until the age of Kleisthenes. ${ }^{119}$ Although Wycherley claims that the Archaic agora did not follow a clear plan or layout, ${ }^{120}$ it is, as Camp notes, very clearly a triangle demarcated by three Peisistratid structures which continued to define the agora until the $2^{\text {nd }}$ century when the Stoa of Attalos was constructed in the eastern corner (Fig. 1). ${ }^{121}$ These

\footnotetext{
116 Alcock, (2002), 28.

${ }^{117}$ For instance, would one qualify a boundary stone as a building or a sculpture? Neither seem quite right. Yet "monument", the most apt word to describe such a thing, must in this case act as the overarching term for all the following examples. It would also be pedantic and unnecessarily complicated to create separate categories for each case study - defeating the point of subheadings altogether!

118 Camp, (1994), 11.

119 Camp, (1994), 11.

${ }^{120}$ Wycherley, (1962), 61.

${ }^{121}$ Camp, (1994), 9.
} 
three structures triangulating the agora are the Altar of the Twelve Gods on the northern apex, the fountain house to the southeast, and the cluster of buildings to the southwest, the most prominent of which was dubbed "Building F" by excavators. ${ }^{122}$ Two of these apices - the Altar of the Twelve Gods and the buildings to the southwest - are joined by the Panathenaic Way, and serve as the groundwork for some of the most important monuments of Classical Athens. On the other hand, the fountain house acted as a source of water alongside an additional Peisistratid structure - the great drain running south to north under the western street - drawing citizens to the space for a practical purpose. ${ }^{123}$ Therefore, the placement of monuments from the inception of the agora was defined by tyrannical origins, something the Athenians would have to rectify as they shifted into democracy.

\section{Sculptures}

\section{Boundary Stones}

Perhaps the best example of this rectification stems from the least significant of the newly emergent structures: boundary stones. Excavated from the south of the agora are two boundary stones of Parian marble inscribed with letter forms dated to $500 \mathrm{BC}$ reading "horos eimi tes agoras" (I am the boundary stone of the agora) (Fig. 2). ${ }^{124}$ Camp notes that these stones were placed in relation to the entrances of the agora and assumes that other entrances to the square were also marked. ${ }^{125}$ These boundary stones indicate two things. Firstly, they confirm yet again the multipurpose nature of the agora as a religious centre no less important than its civic or political function, since stones typically marked out religious spaces and sanctuaries, therefore denoting the Agora as a sacred space. ${ }^{126}$ This assertion can be corroborated by literary evidence, such as Andokides whose exiled status stopped him from entering sacred places, once of which was the agora as well as Aeschines who describes a list of people barred from entering the agora (3.176).

The purpose of the boundary stones can also be extrapolated from three perirrhanteria (water basins) found in the agora as well. Used for purification rites upon entering a sacred space,

\footnotetext{
122 Thompson, Wycherley, (1972), 27.

${ }^{123}$ Camp, (1994), 10.

${ }^{124}$ Camp, (1986), 38, 48. An excavator of the agora - allegedly - has this as a tattoo.

125 Camp, (2010), 56.

${ }^{126}$ Camp, (1990), 59.
} 
these so-called "holy" basins would mark the agora as sacred. Although two were not found in situ and we can only speculate as to their original locations, the stump of a marble pedestal used to support these basins was found to the east of a boundary stone, separated by a difference in soil level. ${ }^{127}$ This suggests three possibilities: either the perirrhanterion was built next to the boundary stone at a later date as an accompaniment, the perirrhanterion replaced the boundary stone in a similar location, or that the site of the boundary stone carried with it a significance marked by the original stone, and the memory of that significance persisted enough for a new marker to be placed there even if the old stone did not survive. Each of these possibilities are interesting and all support the idea, to varying degrees, that places carry significance due to the memories with which they are embedded, even when the original memory fades or is obscured.

Secondly, in addition to marking out the agora as a sacred space, the boundary stones also define the agora as a public domain. While the Peisistratids may have defined the shape of the agora, it is the democratic Athenians of the Kleisthenic era who defined its purpose. By marking the territory as public alongside the introduction of buildings sponsored by the demos, the boundary stones effectively cut off private building programmes, such as those of the Peisistratids. ${ }^{128}$ Thus, the era of wealthy families exerting their influence on the polis through their patronage was over, as they could no longer build within the civic centre of Athens. When these boundaries are considered alongside the Bouleuterion and the Stoa Basileus, the message is clear: Athenian politics would now be sponsored by the demos for the demos. Furthermore, when considering the likely probability that Antenor's Tyrannicides served as the centrepiece of this newly minted civic space, the message is even clearer: there is no longer any room in Athens for tyranny. Therefore, the re-appropriation of the agora from its Peisistratid beginnings can be represented through change as minor as redefining the borders of the space - a process that did not even involve any physical changes to the borders themselves.

\section{The Altar of the Twelve Gods}

Though not primarily a political structure, the Altar of the Twelve Gods embodied the erasure of Peisistratid influence on the foundation of the agora, but also, on Athens as a polis. Located at the northern entrance of the agora via the Panathenaic Way, the Altar of the Twelve Gods

${ }^{127}$ Camp, (1990), 59; Camp, (2010), 56.

${ }^{128}$ Anderson, (2003), 94. 
occupies a significant space measuring $9.35 \mathrm{~m}$ by $9.85 \mathrm{~m}$. It consists of an altar, the peribolos (enclosure) which surrounds it, and a parapet onto which the figures of the twelve gods were presumably sculpted. ${ }^{129}$ Although there are "prehistoric sherds" excavated beneath the area which are consistent with its previous habitation, there is no way to identify whether a structural predecessor marked the space as significant prior to the altar's erection. ${ }^{130}$ Both archaeological and literary evidence suggest that the altar, or at the very least the parapet, ${ }^{131}$ was rebuilt at least once which means that the life of the structure can be subdivided into two phases in terms of dating.

Phase one and the inception of the altar can be attributed to the archonship of Peisistratid the Younger. According to Thucydides, the tyrant "ton dodeka theon bomon ton en tei agorai arkhon anetheke" (erected the Altar of the Twelve Gods in the Agora as Archon (6.54.6-7). This claim is consistent with the material evidence, as the ground level of the yellow poros peribolos as well as its decorative motifs of hawksbeak moulding and disc ornamentation can be dated to the Archaic period. ${ }^{132}$ More specifically, the archonship of Peisistratos the younger dates to between 522/1 and 512/1, with the earlier date being more plausible for four reasons. Firstly, the altar is strongly associated to the Peisistratid road improvements and the erection of herms, both of which can be attributed to Hipparkhos - suggesting that the altar was built under his supervision, or at least while he was still alive. ${ }^{133}$ Long furthers this suggestion, arguing that the altar may have marked the mid-point of the herms that were used as markers for roads emanating out from the agora to the rest of Attica. ${ }^{134}$ This leads to Herodotos, who not only identifies the altar as the point from which roads were measured (2.7.1), but is also the earliest literary source to mention the altar in a historical episode dated to 519 (6.108). ${ }^{135}$ Thirdly, a fragment of an archon list inscribed in 425 preserves the letters "STRAT" for the

${ }^{129}$ Crosby, (1949), 97.

${ }^{130}$ Crosby, (1949), 103.

131 The base of the altar remained the same from its founding to its abandonment when the blocks were covered in the $2^{\text {nd }}$ or $3^{\text {rd }}$ century $\mathrm{AD}$, a date consistent with the Herulian invasion (Crosby, 1949, 99).

${ }^{132}$ According to Crosby, the closest parallel to hawksbeak moulding can be found at the Treasury of Selinus at Olympia, which is dated to the second half of the $6^{\text {th }}$ century. The use of the disk ornament in lieu of a volute was also present in Aegina at this time (1949, 97).

${ }^{133}$ Crosby, (1949), 100.

${ }^{134}$ Long, (1987), 160.

${ }^{135}$ In it, Herodotos also describes Athenians sacrificing the twelve gods at the altar, as well as Plataeans who came under the protection of Athens by sitting under it - thus setting the precedent for one of many examples wherein the Altar of the Twelve Gods acted as a place of supplication. So often, that it was initially mistaken by modern scholars as the "Altar of Pity" which Pausanias describes (e.g. Crosby, 1949, 102; Wycherley, (1959), 41). This theory was debunked by Vanderpool, who observes that Pausanias refers to the Athenian Agora only as the "Kerameikos", which means that he must have seen the Altar of Pity in a different agora, most likely the Roman agora which had been developed by the $2^{\text {nd }}$ century AD $(1974,43)$. 
archon of 522/1, which may well be part of "PEISISTRATOS", though as with any incomplete epigraphic evidence, this conclusion is circumstantial at best. ${ }^{136}$

Finally, the earlier dating seems consistent with establishment of the cult of the twelve gods in Athens, since there is no evidence that the twelve gods were worshipped there in Solonian times. ${ }^{137}$ This detail is also significant in understanding the strong Peisistratid associations of the altar in its first phase. Early Greek cults were often founded in conjunction with an altar sponsored by a wealthy leader - illustrating a nexus of relationships between religion, monument, and clout. ${ }^{138}$ In the case of the Peisistratids, it is also possible that the Altar of the Twelve Gods was linked to the Homeric Hymn of Hermes. Johnston makes this argument based on the fact that baby Hermes in the hymn carves out a tortoise's flesh with a glyphanos - a term mainly used to describe a sculptor's chisel, that Hermes cuts up twelve pieces of meat for sacrifice when he reaches Pylos as if dedicating one to each god, and topographical similarities between Pylos and the Athenian Agora (Hymn to Hermes, 41, 128). ${ }^{139}$ Pylos in itself is significant, as it is the kingdom of the Peisistratids' Homeric ancestor Nestor. ${ }^{140}$ Moreover, if indeed the altar and the hymn are contemporary with Hipparkhos, then that would also corroborate his erection of herms (Plato, Life of Hipparkhos, 228D-229A).

On a more abstract level, Johnston argues that the at the centre of the Homeric Hymn to Hermes lies a conflict between older and younger brother; the hymn depicts Hermes sympathetically, eventually earning the favour of Zeus and Apollo through skill. ${ }^{141}$ The idea of sibling rivalry ties to the Peisistratids not only because Hippias and Hipparkhos are brothers, but also to their semi-mythical ancestor Kodros. Unlike the other established families of Athenian nobility, the Peisistratids were relatively new; their ancestor Kodros was an immigrant from Pylos who earned his descendants' status through service to Athens. ${ }^{142}$ Therefore, the Peisistratid family was effectively the "younger sibling" of the Athenian elite, and their success through continued patronage to Athens is perhaps, celebrated by proxy through the Homeric Hymn's celebration of Hermes. If not composed for the unveiling of the altar, then at the very least, the Homeric Hymn to Hermes makes sense as one of the Homeric recitations made mandatory in the Great

\footnotetext{
136 Crosby, (1949), 100.

${ }^{137}$ Crosby, (1949), 100.

${ }^{138}$ Long, (1987), 163.

139 Johnston, (2009), 5, 10-12.

140 Johnston, (2009), 12.

141 Johnston, (2009), 12.

142 Johnston, (2009), 12.
} 
Panathenaia by the Peisistratid family. ${ }^{143}$ Moreover, regardless of where it was performed, the depiction of Hermes as a sculptor strengthens the connection between the mythology of the tyrants and the Altar of the Twelve Gods as a place of memory.

However, the northern apex of the Agora cannot serve as a constant reminder of Peisistratid patronage, and this is reflected in the changes made to the altar in its second phase. The second phase is defined archaeologically by black glaze pottery contemporary with a second sill course of the peribolos, dating to 430-420. This date is reinforced by the grey poros used to construct the second sill course, which is a material also found on the Hephaisteion and the Nike Bastion dated to 449-444 and 437/6 respectively. ${ }^{144}$ Thucydides describes an interesting phenomenon, wherein when the Athenain demos "prosoikodomesas" (extended) the length of the parapet, they "ephanise toupigramma" (erased the inscription) (6.54.7), undoubtedly referring to the dedication of Peisistratos the younger. Thucydides then goes on to say that in contrast to the erasure in the agora, Peisistratos' altar dedicated to Pythian Apollo still stands with words to the effect of "mnema tod'hes arxes Peisistratos Hippiou huios theken Apollonos Puthiou en temenei" (Peisistratos, son of Hippias, set up this monument of his archonship in the precinct of Pythian Apollo) (6.54.7). Anderson notes that although the archaeological evidence for the changes in the altar fit the timeline of an Athens rebuilding years after the Persian sack, it does not actually reflect a lengthening of the parapet. Therefore, he suggests that what Thucydides describes was an even earlier event contemporary with the shift of the Athenian regime. ${ }^{145}$

Although Crosby uses the survival of this second dedication as evidence that the Athenian erasure of the Altar of the Twelve Gods' inscription was merely for practicality and not some anti-tyrannical effort, she fails to consider the broader context of the agora. Unlike in the temenos of Apollos where Peisistratos is allowed to dedicate as a private individual or even an archon, within the civic space of the agora following the establishment of the Kleisthenic democracy, the reminder of a Pesistratid serving as archon stands as a blatant contradiction to what the space now represents, especially considering its newly constructed civic buildings as well as the Tyrannicide sculptural group quite possibly in close proximity to the altar itself. Moreover, after the establishment of boundary stones marking the agora in $500 \mathrm{BC}$, the private citizen was no longer allowed to build within the space - meaning that Peisistratid patronage,

\footnotetext{
143 Johnston, (2009), 10.

${ }^{144}$ Crosby, (1949), 98.

145 Anderson, (2003), 94.
} 
or patronage of any sort - could not exist within this boundary. Thus, the Peisistratid connections to the altar and cult of the twelve gods were erased alongside this inscription. Instead, the legacy of the Altar of the Twelve gods is one of sanctuary and supplication, leaving modern scholars only the power to speculate on what may have been. ${ }^{146}$

\section{The Tyrannicides}

The Tyrannicide statues stood as symbols of democracy in the agora while, at the same time, exemplifying the ways in which the Athenians chose to remember their own history. Although the sculptures and stories of Harmodios and Aristogeiton are well-replicated, a closer examination exposes the lack of information available to us regarding their conception. Not only is it uncertain as to when the statues were first erected, what form they took, or where specifically they stood, why exactly would the Athenians want to commemorate two men who - in actuality - had very little to do with the overthrow of the Peisistratid tyranny or the dawn of the Kleisthenic democracy? Yet, the answer to this question seems self-evident in the survival of their false legacy and the instrumental role they played in the evolution of the agora as a democratic space. Thus, although the intentions behind the inception of the Tyrannicides may be lost, the purpose which they served and the narratives which they represented as a result of their reception are perhaps even more worthy of exploration.

The original Tyrannicide statues are shrouded in mystery. Attributed to the sculptor Antenor in literary sources, bronze statues of Harmodios and Aristogeiton were sculpted sometime around the turn of the $5^{\text {th }}$ century and stood somewhere in Athens - most likely in the agora before being stolen by the Persians in the sack of $490 \mathrm{BC}$ and taken to Susa, later to be returned by Alexander the Great in time for Pausanias to see them (1.8.5). ${ }^{147}$ Anything more than this statement would veer into the realms of uncertainty, and although many have speculated on their possible dating, form, and who commissioned them, there is a more valuable discussion to be had on what we do understand. Firstly, it is significant that the sculptures were important enough - either visually or ideologically - to be taken and contested over, even after several

\footnotetext{
${ }^{146}$ A rather amusing episode appears in Plutarch's Life of Nikias. In his list of bad omens warning Athenians against the Syracusan expedition, Plutarch includes an instance where an unnamed man leaps to the Altar of the Twelve Gods and mutilates himself with a stone in a manner echoing Alcibiades' mutilation of the herms (13.2). Whether this is fact or fiction is completely unverifiable, though the disturbing image is perhaps why the altar falls out of favour with literary evidence following the turn of the $5^{\text {th }}$ century. Why someone would do this, however, is completely beyond my speculative capacities.

${ }^{147}$ Taylor, (1991), 13.
} 
hundred years, as opposed to outright destroyed like most Athenian monuments in the Persian sack. Secondly, the Athenians themselves cared enough about the Tyrannicides that they were replaced by a new version dated to $477 / 6$, fairly recently after the end of the Persian Wars. ${ }^{148}$ This was an unprecedented act of honour by the Athenians, who had previously reserved their sculptures for heroes, gods, and graves as opposed to mortals in a public setting, and they would stand alone as the exception for over one hundred years. ${ }^{149}$

Fortunately, there is more to be said about the replacement sculptures. Crafted by Kritias and Nesiotes, the new Harmodios and Aristogeiton are distinctly characterised by both their respective facial features and poses, contributing to a unique ethos (Fig. 3). The older Aristogeiton wears a full beard and a defensive posture, extending his left arm draped with a cloak directly forward, while the younger Harmodios is more aggressive, raising his right arm directly above his head to strike - but leaving himself open to damage. The sculptures were accompanied by an elegiac couplet on their base, reading "e meg'Athenaioisi phoos geneth', henik' Aristogeiton Hipparkhon kteine kai Harmodios...patrida etethen" (A great light it was for the Athenians, because Aristogeiton and Harmodios killed Hipparkhos...They made their fatherland...) (IG I ${ }^{3}$ 502). ${ }^{150}$ The killing of Hipparkhos is linked causally through the use of henika to the "light" of Athens, the implication of which is certainly the rise of democracy following a liberation from tyrants. This narrative is one which the viewer re-enacts each time they view the statues with the accompanying inscription, and thus, a memory they draw from the place. Ober suggests that the sculptures' moment of stillness before action further encourages the viewers to complete that narrative for themselves by thinking about the aftereffect of the strike, thereby building an anti-tyrannical sentiment that is explicitly linked to democracy. ${ }^{151}$

\footnotetext{
148 This date is preserved by the Mamor Parium as the "Archonship of the Athenian Adeimantos" (IG.12.5.444) and is contemporary with the Severe Style of sculpture.

${ }^{149}$ Camp, (1990), 89; Taylor, (1991), 15.

${ }^{150}$ The beginning lines of this couplet can be restored partially from two fragments of marble excavated by the American School at Athens, matching its appearance in Hephaistion's chapter on metre in which he discusses the difficulty of using the name "Aristogeiton" in hexameter verse (Hephaistion, 16). Although the epigram was attributed to Simonides in Poetae Lyrici Graei, Meritt argues that this is an uncomfortable attribution given Simonides' love of wealth and associations with Hipparkhos (1936, 355-356). Meritt also goes to suggest that that while the dating of the excavated inscription is likely contemporary with the second iteration of statues due to the use of a particularly distinctive dotted theta, the base was probably a recreation of an original once accompanying Antenor's statues $(1936,358)$.

${ }^{151}$ Ober, (2005a), 216.
} 
Yet, given the actual sequence of events leading up to the rise of Kleisthenic democracy, this "memory" rests upon seemingly fabricated foundations. Neither Herodotos nor Thucydides view Harmodios and Aristogeiton as agents of change. Herodotos calls the Alkmaionids the true liberators of Athens, with the Tyrannicides doing nothing but "exegriosan tous hupoloipous Peisistratideon Hipparkhon apokteinantes" (make the remaining Peisistratids mad by killing Hipparkhos) (6.123.2). Thucydides elaborates, and was the first to relate the now-famous story of Harmodios and Aristogeiton as the spurned lovers. Hipparkhos, who lusted after Harmodios unsuccessfully, engineered his own downfall through forbidding Harmodios' sister from bearing the basket in an unspecified procession - likely to be the Panathenaia given the circumstances of Hipparkhos' murder (6.56.1) - while Aristogeiton was merely motivated through his jealousy, "phobetheis ten Hipparkhou dunamin me bia prosagagetaiauton" (fearing that (Harmodios) would be taken by the force of Hipparkhos) (6.54.3).

For Thucydides, it was neither Harmodios and Aristogeition, nor the Alkmaionids who ended tyranny in Athens, but the Spartans (6.53.3). While both historians agree that the period following the murder was much more severe under the reign of Hippias, Thucydides goes one step further to claim that it was not even Hipparkhos, but Hippias, who had been the reigning tyrant at the time of the murder (Herodotos, 5.62.2, 6.123.2; Thucydides 6.54.5, 6.59.2). ${ }^{152}$ However, he does also acknowledge that his digression on the Tyrannicides was to show that "oute autous Athenaious peri ton spheteron turannon oude peri tou genomenou akribes ouden legontas" (the Athenians themselves are not accurate in speaking about their own tyrants or events) (6.54.1-2), indicating that he is speaking against a majority opinion. Ultimately, the sceptical account is the one which survives within the Athenian historiographical tradition, with the author of the Athenian Constitution echoing Thucydides and Herodotos' narrative and placing emphasis on the executions and exiles which took place, driven by Hippias' paranoia (18.1-19.2). Dover argues that the comprehensive nature of the Athenian Constitution suggests that the author had also drawn from the lost Atthis of the fourth century Athenian Androtion. ${ }^{153}$

On the other hand, non-historical literary sources offer another perspective on the reception of the Tyrannicides throughout Athens. Plato gives a slightly different interpretation of events on two occasions. In Hipparkhos, Sokrates directly references Thucydides' interpretation of

${ }^{152}$ Dover, (1965), 58.
${ }^{153}$ Dover, (1965), 59. 
events, calling the idea that the murder occurred due to the slight of the basket "euethes" (simple-minded) (229c). It was instead, a handsome and noble youth who had caused the dispute, when he "suggenomenon toi Hipparchoi kataphronesai ekeinon" (fell in with Hipparkhos and looked down upon them), after previously admiring the two men "hos sophous" (as wise) (229d). In the Symposium, the view of the two men is more noble and romanticised, as Pausanias uses them as a positive example of the pederastic relationship and its benefits to the state. According to Pausanias, "Aristogeitonos eros kai he Harmodiou filia bebaios genomene katelusen auton ten arkhen" (when the eros of Aristogeiton and the friendship of Harmodios became strong, they put an end to their leadership) (Plato, Symposium, 182c5).

Although these divergences may have existed purely for the sake of rhetorical argument, particularly in the case of the Symposium given the context of Pausanias' own famous pederastic relationship, they nevertheless illustrate an aspect of what the Tyrannicides symbolise. In Hipparkhos, it is their direct competition with Hipparkhos over the influence of young nobles which is emphasized. The fact that "sophous" is the point of contention brings an aspect of ideological difference that the more conventional story of the basket incident does not have, emphasized by its characterisation as "euethes." This account does not necessarily conflict with Pausanias in the Symposium, who chooses instead to focus on the benefits of a pederastic relationship - one of which is the deposition of tyrants. Moreover, even if these characterisations exist expressly for the purpose of rhetoric, it would not be outlandish to assume that they represent an interpretation of the events held by some Athenians at any point in time, given the length of the Tyrannicides' survival - just as the historians held onto their own scepticism.

The most dominant narrative of the Tyrannicides, or at least the one which existed in the public sphere of the Athenians, was that of their anti-tyrannical triumph. In the so-called "Harmodios skolia" from the early $6^{\text {th }}$ century, ${ }^{154}$ the singer of the drinking song describes the two as the ones who "ton turannon ktaneten isonomous t'Athenas epoiesaten" (killed the tyrant and established equality in Athens) (Page, $P M G, 893$ ). The song then claims that the two are "nesois d'en makarwn" (in the isles of the blessed), keeping the company of Akhilleus and

\footnotetext{
${ }^{154}$ Shear, (2012), 33. This dating seems to be the scholarly consensus, while Anderson (2002) suggests that the skolia are undatable (202-203).
} 
Diomedes (Page, $P M G$, 895). Here, the conflation of events is often noted, with the slaying of Harmodios being the cause of the establishment of isonomia in Athens. However, what is overlooked is the performative aspect of the lyrics, in which the singer repeats "en myrtou kladi to xiphos phoreso hosper Harmodios kai Aristogeiton" (I will carry a sword in a bush of Myrtle like Harmodios and Aristogeiton) (Page, $P M G$, 893, 895). Much like the ritualistic aspect to the reading of an inscription or the viewing of a sculpture, the recitation of an agentive lyric in the laudatory setting of the symposium again, reflects the power of collective memory. In this particular version of the narrative, it is the two men, driven by their hatred of tyranny, that the Athenian wishes to emulate and in doing so, earn himself a place on the isles of the blessed. It is a narrative which simultaneously celebrates the past, present, and future. While Harmodios and Aristogeiton enjoy prosperity based on their actions, the Athenian, through emulation, is also promised the same fate - emphasized by the future tense of "phoreso". Recitation of the skolion, despite its origins in a fairly aristocratic setting, was also widespread as the genre gained popularity in the $5^{\text {th }}$ century. ${ }^{155}$ The song is, therefore, not only a preservation of memory through the repetition of words, but also through the promise of repeated actions.

Perhaps the best evidence for the dominant narrative of the Tyrannicides in the public discourse of Athens comes from a smattering of legal sources. A decree dated between 429 and 424 reveals three categories of individuals eligible for sitesis - permanent dining rights in the Prytaneion (IG $\mathrm{I}^{3}$ 131). ${ }^{156}$ The name of the first group is badly damaged, with Ostwald suggesting their being Eleusinian Priests. ${ }^{157}$ The second group in question, and most relevant to this discussion, is "tois Harm[odio] kai Aristogeitonos hos an ei engutata genos" (for those closest in descent to Harmodios and Aristogeiton), followed by the winners of any Panhellenic games. This decree seemed to have a lasting effect, with two references in later speeches. Firstly, Isaios' Dikaiogenes slanders Dikaiogenes for “huperidon men ten en prutaneioi sitesin" (hating the sitesis in the Prytaneion) and also mentions his "kataphronesas de proedrion kai ateleion, ha tois ex ekeinon gegonosi dedotai" (looking down upon the special seating and the exemptions, which were given to the descendants of that race). To punctuate his point, Isaios adds that "Aristogeiton ekeinos kai Harmodios ou dia to genos etimethesan alladi a ten

\footnotetext{
155 Kremmydas, (2012), 219.

156 While it is tempting to restore the issuer of this decree as Perikles based on the corrupted lettering in the third line of the text (---ik-es), there is insufficient evidence to do so.

157 Ostwald, (1951), 28.
} 
andragathian, hes soi ouden metestin" (those men, Aristogeiton and Harmodios, were honoured not because of their family but because of their bravery, of which you have no share) (5.47). These words not only demonstrate that the descendants of Harmodios and Aristogeiton continued to enjoy the honours of sitesis until the 380 s to which this speech was dated, but also that they were granted the additional perks of privileged seating at public festivals and exemption from liturgies. Moreover, the last slight designed as an attack on Dikaiogenes by comparison contrasts his nature with the Tyrannicides, whose selfish exploits described by the historians are characterised here as nothing but brave - indicating the dominance of this narrative.

Similarly, in Deinarkhos' Against Demosthenes, the Tyrannicides and their honours feature once again in invective. Deinarkhos claims that Demades unjustly bestowed upon himself honours "kata tou demou" (against the demos), and that Demosthenes allowed him to "en tei agorai khalkoun stathenta kai tes en prutaneioi siteseos kekoinonekota tois Harmodiou kai Aristogeitonos apogonois" (erect a statue of bronze in the agora and share in sitesis in the Prytany with those born of Harmodios and Aristogeiton) (1.101). This most likely references the instance where Demades went to Alexander to entreat him on behalf of Athens following the destruction of Thebes, around 335 - fifty years after Isaios' Dikaiogenes (Plutarch, Life of Demosthenes, 23.5). Once again, the Tyrannicides and their descendants are used as exemplars to which the target of the invective could never live up, though Demades in this instance, has fashioned himself after Aristogeiton and Harmodios - presumably for engaging in diplomacy that helped Athens avoid the same fate as Thebes. Thus, the implication is that not only did the Tyrannicides end tyranny and usher in a new age of democracy, but they also acted as the saviours of the polis. Moreover, the orators making reference to Harmodios and Aristogetion in their speech would have most likely stood, alongside the jury, in the agora itself thereby reinforcing the strength of their argument through their proximity to the sculptures as the onlooker could turn towards them and recall the deed for themselves. In this way, Harmodios and Aristogeiton were extra special as they were the only men afforded the honour of participating in civic activity through their presence in the agora.

It is here, where monument and place once again occupy the forefront of the discussion. Demades' erecting of a bronze statue in the agora in 335 was at his time, a relatively new practice. Until Konon and Euagoras received bronze statues in the agora for defeating the Spartan fleet at the battle of Knidos in 394/3, the Tyrannicides had stood as the only mortals 
honoured with bronze statues in the agora (Xenophon, Hellenika, 4.3.10; Demosthenes, 20.6870). The exceptionalism of the Tyrannicides is emphasized by the fact that they seem to be the first Athenian statues devoid of function or associated cult practices. The only concrete evidence for a cult of the Tyrannicides is found in the Athenian Constitution, where the author describes the duty of the polemarch to "tois teleutekosin entoi polemoi kai Harmodioi kay Aristogeitoni en agismata poiei" (make an offering to those who perished in war and to Harmodios and Aristogeiton) (58.1). However, there is no evidence that this occurred at their statues, and it is more likely that the enagisma was performed at their graves in the Kerameikos, alongside the graves of the other war dead which the author mentions in the same sentiment. ${ }^{158}$ Meanwhile, they also received libations and sacrifices, as well as songs and honours by sometime prior to $340 .{ }^{159}$ Thus, the only "ritual" performed at the statues would be to view them and read the inscriptions, and in doing so, "remember" back to the act of Tyrannicide as the primary agent of social change - a narrative that seemed to dominate the public sphere of Athens.

The construction of this narrative is important to understanding the place of the Tyrannicides, especially considering the murky history of the Athenian shift in constitutions. As is made clear by historical sources, the death of Hipparkhos did not weaken Peisistratid dominance in Athens. Rather, a chain of events leading to a violent uprising of the demos resulted in the expulsion of the Peisistratids. It was Kleomenes, a Spartan king, who overthrew the Peisistratids in 510 BC (Herodotos, 5.65.1-5.65.4; Thucydides, 6.59; Athenian Constitution, 19). What followed was not a period of immediate stability, but one defined by a contest for power between two wellborn Athenians: Kleisthenes and Isagoras (Herodotos, 5.66.1). This struggle eventually culminated in Kleomenes and Isagoras banishing seven hundred families from Athens and attempting to dissolve the boule (5.72.1), an action that was met with what Ober calls a "threeday riot." 160 It was only after the Athenian demos reclaimed the polis and put Isagoras and his supporters to death that Kleisthenes returned, and although he is known for his reforms of 508/7- it was Isagoras who held the archonship that year prior to his demise (Herodotos, 5.72.4-5.73.1; The Athenian Constitution, 21.1). This riot, for Ober, was the turning point at which the demos seized power for themselves. Kleisthenes then, was able to stand as the

\footnotetext{
158 Anderson, (2003), 202.

159 Shear, (2012), 30, 35.

160 Ober, (1996), 36.
} 
figurehead of this new democracy not because of his status alone, but because of his ability to recognise the changing tide of the polis - framing himself as the hetairos of the demos. ${ }^{161}$

The Tyrannicides and their sculptures served two main purposes in smoothing over the constitutional transition: simplification and constructing an illusion of continuity. Given the complicated and violent nature of this constitutional change, it makes sense for the Athenians to construct a more linear narrative as the basis of their democratic identity. As memory, particularly collective memory, is most prominent when simplified and schematised, it is easier to attribute a complex dispute over power across the course of several years to one event helmed by a prominent individual. ${ }^{162}$ In this case, the constitutional change from tyranny to democracy required figureheads to act as its heroic founders. Harmodios and Aristogeiton were perfect for this. Not only did they kill a tyrant, but more importantly, both had either died immediately or in the immediate aftermath of the killing. Thus, the Tyrannicides were the perfect blank slates onto which the Athenians could project their own narrative. Moreover, although the ancient historians were probably correct in saying that the men acted out of self-interest as opposed to a desire to topple tyranny and usher in an age of democracy, their version of the Tyrannicides' motives is no less speculative than those who believe in the latter. In truth, there is no way to know what the two men were thinking or planning - validating all possible justifications by nature of their invalidity. ${ }^{163}$

By focusing on the circumstances of Hipparkhos' death as the operative event for the new democracy, the Athenians elided some unsavoury aspects of their constitutional shift. The most obvious of these is Spartan involvement, seeing as Kleomenes was the one to drive the Peisistratids out of Athens. However, what is more troubling is the cyclical nature of the events following the Peisistratid downfall, as presented in Herodotos' narrative. Here, the Akropolis is the recurring space of contention; both the Peisistratids and Isagoras occupied the Akropolis when their powers were threatened, and both parties eventually lost the siege - suffering banishment or death $(5.64 .1,5.72)$. Not only that, but Herodotos also tells of an Athenian named Kylon prior to the Peisistratids, who was "epi turannidi ekomese" (interested in tyranny)

\footnotetext{
161 Ober, (1996), 52.

162 There is one well-attested example where a polis, in the face of immediate and compelling political circumstances, discarded one founding hero and adopted a new one, that being Amphipolis' replacement of Hagnon with Brasidas (Thucydides, 5.11.1). This serves as a precedent to the re-fashioning of narrative happening in Athens.

${ }^{163}$ Lavelle (1993), 56.
} 
and had attempted, unsuccessfully, to occupy the Akropolis (5.71.1-5.71.2). Therefore, tyranny in Athens did not end with the deposition of the Peisistratids, since Athens had always been a polis contested by noble men from established families. It took another three years of mass exile and Isagoras' threat to dissolve the boule for the demos to enact revolutionary change, yet that was also three years of complicity to potential tyrants that the demos had to account for in their newfound democratic era. Therefore, the narrative of the Tyrannicides which the Athenians had crafted deliberately conflates this troubled time period: tyranny had ended with the death of Hipparkhos, and it was not Kleomenes, but two Athenian men, who had slain him. Moreover, given that Hipparkhos had perished in the agora while the Akropolis was the space that twice - and almost thrice - acted as a refuge for tyrants, it makes sense that the Athenians would shift their focus onto the construction of a new civic space: one freed from the baggage of tyranny marked by the presence of the Tyrannicides perpetually prepared to strike.

The fact that Harmodios and Aristogeiton hailed from the Gephyraioi genos, a family which was entirely unremarkable prior to the assassination, further contributed to their usefulness. ${ }^{164}$ Unlike Kleisthenes the Alkmaionid, they had died before they could involve themselves in the political rivalries in the immediate aftermath of Hippias' deposition. The Gephyraioi's lack of notoriety is particularly important considering the nature of Athens under tyranny. Athenian nobility as a concept is one based on the mythologies of lineage, with individuals staking their superiority in unverifiable claims of ancestry. Democracy, instead, has no need to look in the distant past to claim legitimacy in the present. Instead, a democracy's legitimacy is rooted in its immediate decision-making mechanisms which look directly towards the future. ${ }^{165}$ The Tyrannicide sculptures then, constantly assert themselves in the present via their presence in the agora and bridges the gap between these two differing temporalities. While they do represent a past, the nature of its constructed narrative is recent and simple enough to be illustrated in sculpture and, therefore, be constantly recalled by those who engage with the monument in the present.

However, the Tyrannicides also assert legitimacy in representing a false sense of continuity with the past. Just as they were unprecedented commemorations of Athenian men in the agora, so too was the Kleisthenic constitution a new pursuit built entirely from the contemporary

${ }^{164}$ Lavelle, (1993), 50.

${ }^{165}$ Csapo, Miller, (1998), 100-102. 
needs of the demos. In order to rectify this with a polis grounded in a culture of ancestral legitimacy and to hide the violence of a violent change, the Tyrannicides had to appeal to a non-existent tradition. Here, the form of the statues themselves offer a sense of comfort. Although little is known about original group of Antenor sculptures, scholarly consensus suggests that they most likely would have taken the form of kouroi based on the fashion of Archaic sculpture. ${ }^{166}$ Nemetz-Carlson then goes to suggest that these would have followed in the tradition of statues honouring athletes, especially considering the Prytaneion decree which treated both the descendants of Harmodios and Aristogeiton, as well as victorious athletes, with the same honours. ${ }^{167}$ This assertion is reinforced by Brunnsaker, who collects four examples of $5^{\text {th }}$ century amphorae which depict the statue group crowned and concludes that like athletes, they were crowned temporarily. ${ }^{168}$ If this hypothesis is correct, then one can assume that although the Tyrannicides as statues of their type were unprecedented, the Athenians built upon a form of commemoration already familiar to them in order to bypass the unfamiliarity of commemorating Tyrannicide. Like athletes, these individual men had brought benefits to the polis, and should be remembered as such - a practice that persisted even after the original statues were replaced; like athletes, there was no uncomfortable tension between the excellence of the individual and the flourishing of the polis, because one leads directly to the other, mediating the potential tension between the two caused by commemorating individuals on behalf of democratic success. ${ }^{169}$

In addition to a possible athletic precedent, the Kritias-Nesiotes sculptures seem to also take on mythological associations through the visual quotation of a Heraklean motif. Taylor observes that the sculptures take on what is essentially a dissection of a common Heraklean pose found on both black and red figure vase painting pre and postdating the sculptures. ${ }^{170}$ In the vase paintings, Herakles raises his right arm above his head, aggressively posturing to strike with his club, while his left arm extends forth with a bow (Fig. 4). Not only is this a mythological connection established through the continuation of a visual motif, but it is one that holds extra significance following the Persian Wars, which enriches the meaning of these sculptures and their associations. Both Herakles and Hippias were linked to the Battle of

\footnotetext{
${ }^{166}$ Nemetz-Carlson, (2012), 45-47. The suggestion that the Kritias-Nesiotes group were an exact copy of their Archaic precedents is strange, given their distinctly severe features. Moreover, logistically speaking, if the Persians had taken the original copy, then surely the sculptors would have had nothing to copy from.

167 Taylor, (1991), 18.

${ }^{168}$ Brunnsaker, (1971), 102-7.

${ }^{169}$ Meyer, (2013), 486.

170 Taylor, (1991), 18.
} 
Marathon where the Athenians had triumphed over the Persians. The Athenians had camped in Herakles' sanctuary before the battle (Herodotos, 6.108, 116), and the Persians had returned under the guidance of Hippias, hoping to re-establish him as tyrant in a puppet state (6.102, 107.1). ${ }^{171}$ The place of Marathon was also one steeped in associations to tyranny, as it was where Peisistratos had first landed with Hippias in 546, establishing their reign in Athens. ${ }^{172}$ This association is highlighted by Herodotos himself, when he depicts Miltiades as evoking Harmodios and Aristogeiton to spur Kallimakhos into engaging with the Persians. In doing so, Miltiades argues, Kallimakhos can "eleutheras poiesanta" (make (Athens) free) (6.109.3).

Therefore, the Athenian triumph at Marathon had been another triumph against the looming threat of tyranny, so the conflation between the imagery of the Tyrannicides and Herakles, the hero whose guidance had been crucial to the Athenians at a time of crisis, goes both ways. In this way, the Persian theft of Antenor's Tyrannicides could also be linked to a narrative of the Persians' desire to deprive Athens of their democracy and reinstitute tyranny, even if that was not the intention. ${ }^{173}$ Therefore, by the time that Pausanias sees a painting of Herakles standing triumphant over the Battle of Marathon in the Painted Stoa (Pausanias, 1.15.3), it is entirely possible that he is seeing the intersection of two narratives: Herakles as a tyrannicide, and the Tyrannicides as a pair of men legitimised through their relation to Heraklean greatness. Through the conflation of imagery, the Athenains blended their sense of myth and reality, as well as their history and present, to create timeless symbols of democratic resistance. Therefore, it is no surprise that the so-called "Harmodios stance" became the "most stable iconographic element in depictions of tyrannicide", ${ }^{174}$ because the narrative had become inseparable from imagery. They merged to a point where it was no longer about the history of Harmodios and Aristogeiton - the Athenian indiviudals who once lived, but the mythology of Harmodios and Aristogeiton - the statues which stand permanently in the agora. Considering the impact of the statues themselves and the strength of the blatantly constructed narrative, it was most likely, never about the former to begin with.

At this point, we should return to and re-examine the conflicting narratives present in the historical tradition. Shear argues that the presence of different stories in both Herodotos and

${ }^{171}$ Evans, (1993), 282; Samons, (2011), 156.

${ }^{172}$ Samons, (2011), 156.

173 Taylor, (1991), 18.

${ }^{174}$ Ober, (2005), 221. This emulation is instrumental to Athenian self-conception in the aftermath of the Thirty, which will be further discussed in the next chapter. 
Thucydides is evidence of separate oral traditions from a variety of disparate groups, from which the historians extrapolated their evidence. ${ }^{175}$ To support her claim, she turns to three $5^{\text {th }}$ century speakers who each present their family in the forefront of the effort to depose the Peisistratids. ${ }^{176}$ In doing so, Shear suggests that these traditions were passed down within families through commemorative practices and rituals, such as burials of the dead, marking those who died with tombs and stelai, or festivals at which kinsmen would congregate and celebrate the continuation of their existence through the swapping of stories, enabling family members of subsequent generations to experience also the collective memory of their community which they did not necessarily experience for themselves. ${ }^{177}$

Shear defines this process as the articulation of identity, in that these smaller collectives can utilise an alternative version of the dominant collective narrative to self-legitimise their unique positions in society, as is typical of collective and social memory. ${ }^{178}$ However, the flipside of a sub-group's definition of identity also enables a better understanding of the commemoration of the Tyrannicides at large. By inhabiting a space in the agora, the Tyrannicides have a monument of collective remembering akin to the private stelai of the deceased, one which is accessible and visible to anyone who wishes to engage with Athens on a civic level. Thus, their presence and commemoration can, in the same way, inform the collective of the Athenian citizenry of their own identity. They are, at the same time, the ancestors who give value to the Athenian democratic polis, but also the present citizen who sets foot in the agora: an ideal to which other citizens ought to strive. Or, as Ma articulates, "it is not "how do you remember who you are?" but "how can you be that which you remember?" 179

What is even more interesting is that, in spite of these conflicting sub-narratives, an overarching theme prevails across every surviving version. That being tyranny has no place in Athens, and the Athenian citizens had always stood up against it. Although the historical sources do treat Peisistratos with leniency, they do so through the lens of democracy justifying his place in

\footnotetext{
175 Shear, (2012), 44.

176 Shear, (2012), 45-46. The three speakers in question are the younger Alkibiades who relates an account of the Alkmaionid defiance against tyranny not unlike what the historians present (Isokrates 16.25-27); Andokides who recollects a story of his grandfather Leogoras (1.106); and Euandros who claims that his family were never the subject of tyrants, because they had been in a perpetual state of stasis against them (Lysias 26, 22). These responses are, of course, reactionary to the anti-tyrannical paranoia of Athens shortly after the deposition of the Thirty, and will be further explored in the following chapter.

177 Shear, (2012), 49.

178 Shear, (2012), 50.

${ }^{179} \mathrm{Ma},(2009), 255$.
} 
Athens by the extent of his "democratic" actions. Most famously, the author of the Constitution of Athens claimed that Peisistratos "diokei...ta peri ten polin metrios kai mallon politikos e tyrannikos" (judged the matters of the city more like a statesman than a tyrant) (14.3). This in turn, invalidates tyranny as a constitutional contender in Athens, fashioning Peisistratos as some sort of proto-democrat to explain the success of his reign. This is done despite the fact that upon his arrival at Marathon in 546, Peisistratos and his family likely faced little to no resistance, even before Peisistratos supposedly demonstrated himself as more democratic in character. ${ }^{180}$ In Aristophanes' Lysistrata, arguably a mockery of the Tyrannicide narrative, ${ }^{181}$ Lysistrata outright states that it was the Spartans who delivered Athenians from the slavish partisanship of Hippias (1149-1156). She goes on to say that they "ton demon umon khlainan empeskhon palin" (draped the democratic cloaks over you again). ${ }^{182}$ Thus, although deviations from the self-fashioned story of Athenian resistance against tyranny were inevitable, it seems that the Athenians had succeeded in stretching a newfound democratic constitution so far into their self-conception of the past, that they no longer remembered an Athens devoid of democracy.

The motive behind the commemoration of the Tyrannicides and the specifics surrounding the erection of their statues in the agora may be lost, but their impact in the cultural memory of the Athenian foundation of democracy is undeniable. In simplifying the complex narrative of the late $6^{\text {th }}$ century, the Athenian reconstruction of narrative was able to mark the turning of an Athenian constitution, while simultaneously creating an illusion of continuity between their past and the immediate present. The presence of the statues themselves were indispensable to this process, as they were a novel monument marking out a fresh civic space as symbols of a newly minted regime that had grown almost completely from scratch. ${ }^{183}$ Simultaneously, they asserted the illusion of a continued democracy and a tradition of tyrannicide through their visual quotations, eventually assimilating into a grander Athenian narrative when the memories of Hippias' assassination conflated into other events. Thus, while the statues "interanimated" the agora by asserting a tyrannicidal presence and defined the space as such, the agora reciprocated by imbuing the statues themselves with the daily practice of Athenian democracy

\footnotetext{
${ }^{180}$ Samons, (2011), 156-157.

181 Azoulay, (2017), 59-60.

182 Anderson, (2003), 208.

${ }^{183}$ Hölscher, (1998), 160.
} 
as it operated as a civic space - demonstrating how two lieux de mémoire can constantly interact with each other to generate meaning and form a unique phenomenon.

\section{Buildings}

In order to contextualise the buildings in the Athenian Agora, we must first, briefly examine the agora's origins and predecessors. Emerging from the Dark Ages, the space known to us today as the Athenian Agora looked to be no more than a private living area. Archaeological evidence dating between 1000 and 600 BC reflects an exclusive use for private housing and burials, and a steady population increase between these four hundred years - with twenty eight graves found dating between 750 and $650 \mathrm{BC}{ }^{184}$ A series of filled wells and the relocation of burial to the southern hillslopes around the beginning of the $6^{\text {th }}$ century suggest that the Athenian Agora had only been laid out at that time, and progressed from that point as a civic space. ${ }^{185}$ However, evidence of pottery indicates that Athens emerged from the Dark Ages as an already flourishing community due to the large quantity of pottery and luxury goods found in the ostentatious burials of the rich, suggesting at the very least a functional ceramics industry and trade with places such as the Levant. ${ }^{186}$ Therefore, there must have been another place which serviced the civic needs of the Athenian community prior to the establishment of the agora.

Literary sources for the location of Athenian civic life prior to the laying out of the agora are rather shadowy but point to an earlier space Oikonomides dubs "the agora in the Old Town." 187 The most explicit account for the existence and use of this place comes from an Apollodoros quotation found in Harpokration dated to the $1^{\text {st }}$ or $2^{\text {nd }}$ century AD. In it, he describes a cult to Pandemos Aphrodite established "peri ten arkhian agoran dia to entautha panta to demon sunagesthai to palaion en tais ekklesiais, as ekaloun agoras" (by the old agora, because in that place all the people once gathered in assemblies, which they called "Agoras") (Harpokration, s.v.). Thucydides, although avoiding the terminology of "agora", speaks of "to de pro tou he Akropolis he nun ousa polis en, kai to hup'auten pros noton malista tetrammenon" (Before the Akropolis was established, the city was there and in the area

\footnotetext{
${ }^{184}$ Camp, (1986), 34.

185 Thompson, Wycherley, (1972), 19. For wells as a sign of private housing, see Camp, (1994), 9.

186 Shear, (1994), 225.

187 Oikonomides, (1964), xii. Not to be confused with the place to which Montero Lamar Hill wishes to take his horse.
} 
beneath it towards the south) (2.15.3). Oikonomides argues that these two are the same place, using archaeological evidence excavated in the area reflecting both dedications to Aphrodite Pandemos, as well as boundary stones to a spring which Thucydides attributes in his description of the Old Town agora to the Enneakrounos established by the Peisistratidai $(2.15 .5-6){ }^{188}$

These observations, in turn, shed light on passages describing possible structures in the Archaic period. In the Constitution of Athens, the author remarks on civic offices prior to the time of Drakon's law reforms and describes the civic buildings they inhabited (3.2). More specifically, he states that "ho men basileus eixe to nun kaloumenon boukolion, plesion tou proutaneiou" (the basileus had what is now called the Boukolion, next to the Prytaneion (3.5). ${ }^{189}$ Furthermore, Plutarch's Life of Solon describes several events happening in the agora, the most notable of which was Solon's mounting of a "herald's stone" and reciting a one-hundred versed poem (8.1-3). While it is entirely possible that both these sources, written hundreds of years after the events had transpired, conflated the agora of the Old Town with the new due to an ignorance of the history of the two locations, that in itself leads to interesting conclusions. For instance, in a case where the Athenian Constitution had most certainly conflated the features of the two agorae by describing the Stoa Basileus as a feature of Solonian times when it cannot be dated prior to the $6^{\text {th }}$ century suggests, through its conflation with "the great Athenian lawmaker", the importance of the Stoa Basileus to the establishment of legislation and constitution. Moreover, if these later authors indeed had no idea of how to date monumental Athenian structures - and there is no reason to assume that they would have been able to - then their mistaken writings are a good indication of the state of Athenian collective memory in showcasing strands of the constructed narrative bound to these places and serving as proof of the power of memory. Thus, in spite of the murky evidence surrounding the Old Town, the shadow

\footnotetext{
${ }^{188}$ Inscriptions to Aphrodite Pandemos found on the south slope of the Akropolis: IG II², 4596; IG II ${ }^{2}$, 657; IG $\mathrm{II}^{2}, 5149$; IG II ${ }^{2}, 5131$. Boundary stones for a spring: IG I ${ }^{2}, 874$; IG I² 875 . For other evidence see Oikonomides, (1964), 1-51. The location of the Enneakrounos seems to be the major point of contention for scholars on locating the agora of the Old Town. Pausanias seems to make no mention of the Old Town agora, instead locating the Enneakrounos in the south of the Athenian Agora (1.14.1). Furthermore, Pausanias seems to make no mention of the Old Town agora. However, Oikonomides refutes hypotheses drawn from Pausanias' writings, as his travels in the $2^{\text {nd }}$ century $\mathrm{AD}$ would have coincided with the construction of the Odeion of Herodes and eclipsed the area (1964), XIV. It is also possible that the fountain house in the south of the Athenian Agora also carried the toponym of Enneakrounos, without being the sacred fountain which Thucydides described (1964), 17. His quip in response to the sceptics against Thucydides is most enjoyable: "surely Thucydides, an Athenian, who lived in the city for most of his life, would never have thought that twenty five centuries after his death the descendants of the Hyperboreans would suppose that he had been incorrect in his observations of his native city" (1964), 16.

${ }^{189}$ Shear, (1994), 239.
} 
it casts over the Athenian Agora provides context in which to situate the timeline of the Athenians' collective memory and will make its return in later discussion.

\section{Building F}

Building $\mathrm{F}$ is a structure dated to the Peisistratid incarnation of the agora with elusive origins but a marked importance. As per earlier discussion, the agora which formed as a result of Peisistratid patronage was triangulated by three significant structures: the altar of the twelve gods in the north, the fountain house in the southeast, and a cluster of buildings in the southwest (Fig. 1). The southwestern apex has since been excavated to uncover a complex consisting of several contemporary buildings dated to the mid- $6^{\text {th }}$ century via pottery remains, ${ }^{190}$ the largest of which was the so-called "Building F". Incidentally, Building F was also the only structure to survive beyond the Archaic period. ${ }^{191}$ Measuring 27 by 18.5 metres, the building was unusually large with no parallel among Archaic or Classical houses. ${ }^{192}$ It encompassed a colonnaded court surrounded by rooms of various shapes and sizes, as well as the remains of a kitchen identified by two fire pits. ${ }^{193}$ The building was most likely used by important persons and their entourage for official purposes, yet a large number of domestic artefacts uncovered alongside it also suggests private use. ${ }^{194}$

Therefore, Camp concludes that Building F was originally the palace of the Peisistratids serving as both the private residence of the tyrants, but also as an administrative centre. ${ }^{195}$ There are two reasons why this hypothesis is particularly tempting. Firstly, the Peisistratids were effectively responsible for laying the foundations of the agora, with the Altar of the Twelve Gods and the fountain house drawing cult and civic activity to the space. If, then, this was an effort to establish a civic centre away from the Old Town based purely on the patronage of the tyrants as a reminder to the Athenians, it would not be a stretch to assume that one of the apices of the triangle be the palace of the Peisistratids themselves. Secondly, the Athenian treatment of the area surrounding Building $\mathrm{F}$ following the downfall of the Peisistratids is also potentially telling. Not only did the Athenians try to preserve Building $\mathrm{F}$ over the rest of its

\footnotetext{
190 Thompson, Wycherley, (1972), 28.

191 Anderson, (2003), 92.

192 Camp, (1994), 10.

193 Anderson, (2003), 92; Shear, (1994), 241.

194 Camp, (1994), 10.

195 Camp, (1986), 95.
} 
complex - even following the Persian sack - it was attached, via parapet and a broad esplanade, to the Old Bouleuterion. ${ }^{196}$ Moreover, the Tholos was built to partially overlap with the structure and continued the use of Building F's kitchens. ${ }^{197}$ These two initial buildings also begin a trend of the agora's southwestern corner being used for centres of civic administration, with some dubbing it the "arkheia" as a result. ${ }^{198}$

Boardman observes that Athenians tend to inhabit "palimpsests of the past" in order to draw identity from place, an idea agreeing with Nora's conception of the lieu de mémoire. ${ }^{199}$ Therefore, it could well be that the Athenians, upon adopting democracy, wished to repurpose the former administrative centre of the Peisistratids to an administrative district of their own. For those in proximity to the living memory of the Peisistratids, doing so sends a message of constitutional change while asserting a sense of continuity through inhabiting the same place for the same purpose. Eventually, the living memory of Athenian tyranny fades, at which point the building becomes just another place in the civic district of Athens as if it were never built by tyrants. On a more practical note, it would also be easier for the Athenians to repurpose such a lavish structure with existing facilities, instead of destroying it merely to make a point.

\section{The Old Bouleuterion}

The Old Bouleuterion is yet another difficult building to reconstruct, once again as a result of its transformations. To the south of Building F, conjoined and accessible via esplanade, is a building opposite to it in nature. Its aesthetic is plain and unpretentious, encompassing an area just large enough to seat the Kleisthenic boule of five hundred. ${ }^{200}$ Therefore, although the sources on the initial phase of the Old Bouleuterion are scarce, the historical necessity for a space to seat the boule can date the structure to the turn of the century. However, at some point in the late $5^{\text {th }}$ century - most probably after the rise of the Four Hundred - a New Bouleuterion was built and the Old Bouleuterion repurposed. As the Scholiast on Aeskhines notes, "meros tou bouleuteriou epoiesan Athenaioi to metroion" (the Athenians made part of the Bouleuterion into the Metroon). Since then, the Old Bouleuterion is referred to in literary sources as the Metroon, possibly due to its proximity to an Archaic temple to the Mother of the gods destroyed

\footnotetext{
196 Anderson, (2003), 92.

197 Thompson, Wycherley, (1972), 28.

198 Thompson, Wycherley, (1972), 25.

199 Boardman, (2002), 26.

200 Thompson, Wycherley, (1972), 33.
} 
in the Persian sack. The Metroon acted instead, as an archive for the laws of Athens, a fact constantly referenced by the $4^{\text {th }}$ century orators (Deinarkhos, 1.86; Demosthenes, 19.29, 25.98; Lykourgos, 1.66).

The only piece of literary evidence dated prior to the Old Bouleuterion's transformation into the Metroon seems to be Aristophanes' Knights, in which the sausage seller describes himself crashing into "ten kigklid" (latticed gates) surrounding the building and causing the prytany to vault over the "druphaktous pantakhei" (surrounding fences) $(641,675)$. However, there are also five pieces of epigraphical evidence dated to the mid-5 $5^{\text {th }}$ century that mention a "Bouleuterion" in some capacity: two are proxeny decrees (Agora I 4977.4-9; IG I² 27.7-11), two tribute lists for the year (IG I² 63.22-25; IG I² 65.52-60), and one seems to concern the display of psefisma (decrees) (IG $\mathrm{I}^{2}$ 85). What is interesting still, is that they all mention placing copies of inscriptions into the Old Bouleuterion as well as on the Akropolis. For instance, IG I" 85 specifies that a decree be erected on the Akropolis, but also "ean de boletai en bouleuterioi exsesto anagraphsai" (if one wants, to write it and stand it up in the Bouleuterion) (6-10). Not only do these inscriptions set the precedent for why the Old Bouleuterion became an archival space following the construction of the New Bouleuterion, but they also reveal the ways in which civic inscriptions were treated in the $5^{\text {th }}$ century. It is important to keep in mind that the primary place for the erection of inscriptions was, at that time the Akropolis. The last decade of the $5^{\text {th }}$ century was soon to change that.

\section{The Tholos}

The Tholos, also known as the Skias, is one of the easiest buildings to identify. Dated between 470 and 460 by ceramic evidence, ${ }^{201}$ the foundations of the Tholos match the descriptions of Pausanias, who describes it as the only round building in the agora (1.51). Much like the Old Bouleuterion, there was nothing remarkable about the building besides its shape and a roof consisting of diamond-shaped tiles. ${ }^{202}$ Although misidentified by Hesykhios as the Prytaneion, the area where the Tholos and the newly purposed Building F stood was most likely known as the Prytanikon. ${ }^{203}$ According to the Athenian Constitution, the prytany dined in the Tholos before arranging gatherings of the boule and demos (43.3); this is corroborated not only by the

\footnotetext{
201 Camp, (1986), 77.

202 Camp, (1986), 77.

203 Thompson, Wycherley, (1972), 41-42.
} 
Scholia on Demosthenes which adds that they dined at public expense (19.314), but also by the utensils excavated there and the repurposing of Building F's kitchen. ${ }^{204}$ Moreover, Andokides mentions that the prytany had slept in the Tholos following the mutilation of the Herms in $415 \mathrm{BC}$ (1.45), while a third of them slept there normally. ${ }^{205}$ Lodging in the Tholos then, represented a readiness to act, and the building itself seemed to symbolise the active functioning of a democracy wherein the contribution and patronage of the demos resulted directly in the facilitation of its decision-making mechanism.

\section{Stoas}

Beyond the southwestern corner of the agora where the civic buildings had concentrated were also the stoas of Athens. While the earliest stoas date to the end of the $7^{\text {th }}$ century, the Athenian stoas marked the first known instance of these buildings as monuments within a civic space to serve, more generally, the city at large as opposed to cults within a sanctuary. ${ }^{206}$ If the agora is the heart of Athens defined by its multipurposed nature, then the stoa is a microcosm of the agora in that the buildings themselves can serve multiple functions. This is evident even in its architectural makeup of a roofed colonnaded porch making use of both indoor and outdoor space. Thus, literary evidence of Athenian stoas reflect anecdotes of passer-by Athenians and philosophers just as well as official congregations. Entertaining all Athenians alike, it is no surprise that the stoa became the focal point of the Attic lifestyle. Here, and in the following chapter, I will focus on the Stoa Basileus and the Stoa Poikile: the two structures particularly relevant to the reassertion of democratic identity in the last decade of the $5^{\text {th }}$ century.

\section{The Stoa Basileus}

Otherwise known as the Royal Stoa, the Stoa Basileus on the northeastern side of the agora is the oldest and most modest of its kind. ${ }^{207}$ Although it is hard to date precisely, the stoa was likely rebuilt following the Persian Sack using old materials contemporary with the Altar of the Twelve Gods. ${ }^{208}$ However, there is no indication of a previous building of the same nature

\footnotetext{
${ }^{204}$ Wycherley, (1957), 179. In the likely event that the Tholos was used as a dining area, it does beg the question of why exactly the building would be round. A circular building is not exactly the optimal use of space, especially if the prytany reclined while dining - as diners ought to do.

${ }^{205}$ Camp, (1986), 94.

206 Osborne, (2009), 243.

207 Thompson, Wycherley, (1972), 83.

${ }^{208}$ Crosby, (1949), 97.
} 
except for an $11^{\text {th }}$ century Submycenaean burial plot which may have marked the space with some significance, but is unlikely to have done so given the Athenians' willingness to build over it as opposed to other Bronze Age monuments they had preserved. ${ }^{209}$ As its name suggests, the function of the Stoa Basileus was to house the Archon Basileus: the spiritual successor to the ancestral kings of Athens who may have inherited some of their civic and religious functions. ${ }^{210}$ Its furnishings of limestone thrones reflect this, and the fact that they were replaced with marble in the $4^{\text {th }}$ century suggests continued and consistent use. ${ }^{211}$ Plato's account of Sokrates' final days suggests that the Archon Basileus oversaw preliminary legal matters: the philosopher remarks that he needed to report to the Stoa Basileus on account of the accusations laid against him (Plato, Euthyphro 2a; Theatetus 210d). Moreover, the Areopagos seemed to have met there occasionally in the $4^{\text {th }}$ century as well, using a rope (periskhoinisetai) to keep their affairs secret from the public (Demosthenes 25.23). ${ }^{212}$

The Stoa Basileus is also a place where different temporalities conflate due to the significance it gains, particularly towards the end of the $5^{\text {th }}$ century. Although the Athenian Constitution had most certainly confused it with another place predating Solon, quite likely in the Old Town, it is nevertheless informative. The author mentions that copies of the laws of Solon could be found on kyrbeis - triangular tablets shaped like pyramids - deposited in the building (7.1). ${ }^{213}$ Moreover, he states that "hoi d'ennea arkhontes omnuntes pros toi lithoi" (the nine archons swore by the stone). That the archons swore by the lithos recurs in both Pollux and Plutarch (Pollux, 8.86; Plutarch, Life of Solon, 25.2). Archaeologically, there is evidence of such a stone north to the midpoint of the Stoa Basileus. Measuring 1 by 3 metres horizontally and 0.4 metres vertically, the monumental slab of tan poros appears to be an unworked stone with a smoothed over top - possibly worn by centuries of use. ${ }^{214}$ There is some speculation as to its origins. Vermeule suggests that it is from the lintel of a Mycenaean tholos tomb salvaged in antiquity and thus regarded as sacred, while Anderson, based on later writers' willingness to conflate the lithos with Solonian events, suggests that it may have been a piece of the Old Town carried

${ }^{209}$ Camp, (1990), 82.

${ }^{210}$ Thompson, Wycherley, (1972), 87.

${ }^{211}$ Camp, (1986), 104.

${ }^{212}$ I should mention also, that there is debate surrounding whether or not the Stoa Basileus was the same structure as the Stoa of Zeus. Although irrelevant to my current argument, the phenomenon does illustrate the ease with which places - and the memories attached to them - can be conflated even in ancient sources. For further discussion, see Thompson, (1937), 64, 225 and Wycherley, (1957), 30.

${ }^{213}$ For the definition of kyrbeis, cf. Pollux 8.128.

${ }^{214}$ Thompson, Wycherley, (1972), 88. 
over to the agora. ${ }^{215}$ Regardless of which speculative conclusion is more believable, that the Stoa Basileus and the lithos were inexplicably linked with the Athenian narrative of lawmaking is undeniable, and it is a phenomenon that may well be a result of the refashioning of the agora following the brief reigns of the Four Hundred and the Thirty.

\section{The Stoa Poikile}

The Stoa Poikile was perhaps the most prolific of the Athenian stoas. Originally known as the Stoa Peisianax "apo Peisianaktos tou ktisantos" (from Peisianax who brought it about) (Scholia on Demosthenes, 20.112), it later took on the title of poikile (multi-coloured) to reflect the paintings displayed there. ${ }^{216}$ Based on ceramic evidence as well as the works of the painters displayed there, the stoa can be dated between 475 and 450 . Thompson argues for a date of 460, given that its architectural features seem contemporary with the Hephaisteion. $^{217}$ Based on Pausanias' uncharacteristically detailed description, the Stoa Poikile seems to be a monumental marvel - displaying the great works of Polygnotos, Mikon, and Panainos which the traveloguer is able to admire 6 centuries later. ${ }^{218}$ Moreover, these paintings seem to follow a theme of Athenian triumph over enemies, with Pausanias describing depictions of victories over Sparta at Oinoe, over the Amazons at Troy, and over the Persians at Marathon - something which is reinforced by the trophies of war also found there (1.15-1.16). ${ }^{219}$ In addition to its monumentality, the Stoa Poikile seemed also to serve many other uses. For instance, two mid- $4^{\text {th }}$ century inscriptions describe possible legal proceedings transpiring there. One refers to "to dikasterion he stoa he poikile" (the court of the painted stoa) (IG II ${ }^{2}$ 1641.25-30), while another more obscured inscription mentions "stoa poikile eis hena kai pentakosious dikastas" (the Stoa Poikile and 501 jurists...) suggesting that courts congregated there on multiple occasions (IG II ${ }^{2}$ 1670.34-35). Moreover, it was their teachings in the Stoa Poikile, from which the stoics earned their name (Suidas). Therefore, the Stoa Poikile was an exemplar of the potential

\footnotetext{
215 Anderson, (2003), 98.

${ }^{216}$ Peisianax himself remains relatively lost to history. Not much is known about him besides the fact that he may have had a son who was an ally of Perikles, and that he may also have been the brother in law of Kimon both of which are said without certainty (Wycherley, (1957), 45). Again, the erasure of Peisianax from the name of the stoa reflects the fickle nature of collective memory.

217 Thompson, (1950), 328.

218 Camp, (1990), 104.

219 These trophies include bronze shields taken from the Spartans at Pylos after the Battle of Sphacteria in 425/4 BC, a version of which was later excavated from a filled cistern (Shear, (1936), 348). Although it is tempting to assume that the excavated shield was exactly what Pausanias saw, the cistern had been filled long before Pausanias' arrival in Athens. However, this does suggest that much like modern museums, the Stoa Poikile most likely displayed more than one copy of the Athenians' noteworthy artefacts.
} 
intersections within the Athenian Agora, where monumentalisation and commemoration stared in the face of daily civic activity. It is then, no surprise that it becomes a point of contention when Athens falls into constitutional turmoil.

\section{Conclusion}

The Athenian Agora was an ideological hotbed owing to a tyrannical origin. From the moment the Athenians established their democracy, they were already tasked with the burden of reclaiming and redefining their civic space. Not only that, but they had to mediate the trauma of revolutionary constitutional change, dealing with a new form of government that no longer depended on the past for legitimacy which was thrust upon a people who were accustomed to doing just that. Therefore, the transformations of the agora through its monuments and buildings reflect both needs. While maintaining the same locations and working with preestablished motifs emanated a sense of continuity with the past, the erasure of the Peisistratids' patronage to these areas - punctuated by the Tyrannicide sculptures ensured that their memory would not survive beyond the contemporary generation. Instead, the memory of the $6^{\text {th }}$ and early $5^{\text {th }}$ century locked within the monuments in the agora is one of an ancestral democratic constitution interrupted briefly by tyranny: an insignificant episode which had been easily eradicated. The strength of this narrative and the influence of place upon it prove more important than ever when considering the actions taken during and after the brief takeovers of the Four Hundred and the Thirty. 


\section{The Age of Constitutional Turmoil: Transformations in the Agora between 411 and the Aftermath of 403}

The period between 411 and 403 was traumatic for Athens. Not only did their grasp on the Peloponnesian War spiral out of control, resulting in their eventual loss to Sparta, but the Athenians' desperate efforts to salvage a losing conflict following the Sicilian expedition led them onto a path of constitutional turmoil. Athenian democracy fell twice to oligarchy, starting with "The Four Hundred", followed by "The Five Thousand", and culminating in the infamous reign of "The Thirty" towards the end of the decade. However, more often than not this rather humiliating period for Athens is remembered for its triumphant end, when the Athenians were seemingly able to set aside their differences in favour of a reconciliated democracy. Through this process and what is now known widely as the "Athenian Amnesty", the demos had ushered in an unrivalled age of democratic stability which would last for eighty years - unsettled only by Macedonian conquest. ${ }^{220}$

However, collective memory is not so easily changed or erased, and despite the Athenians' best efforts to frame their amnesty in the terms of ritual forgetting, the political enmities and ideological divisions fresh in the mind of the restored democracy could not fade so easily. Even if the demos were willing to forget in the aftermath of stasis, memories cannot be erased through sheer force of will since the past is not a passive entity limited by the passage of time, but a constant force resonating in the present. ${ }^{221}$ Not only that, but if communities particularly ancient Greek poleis - are forged through a collective agreement based on shared experiences and memories, which in turn, provide the basis for a shared identity, then surely a democracy restored on the basis of forgetting would have been unstable. ${ }^{222}$ Therefore, it was not forgetting, but rather, a calculated and systematic process of remembrance veiled in the language of forgetting which enabled the Athenians to reconcile. In doing so, the Athenians constructed shared memories and the illusion of a shared past through which they could reconcile the conflict of the present and work towards a common future. ${ }^{223}$

\footnotetext{
${ }^{220}$ Cohen, (2001), 342.

${ }^{221}$ Fentress, Wickham, (1992), 24.

222 Young, (1993), 7.

${ }^{223}$ Young, (1993), 5.
} 
Thus, the purpose of this chapter is to explore the Athenian Agora as a contested lieu de mémoire during the last decade of the $5^{\text {th }}$ century and to trace shifts in the place corresponding to the attempted redefinitions of Athenian constitutional identity. As demonstrated in the preceding discussion, the agora itself was a contested space onto which the ideological battles of Athens grafted themselves. It is, then, no surprise that the agora went through multiple changes during this period as a result of the dominant political group in Athens' attempts to repurpose the space for their own agenda. These changes occurred with varying degrees of success, and as a result of these contestations the Athenian Agora which stood at the beginning of the $4^{\text {th }}$ century would be a markedly assertive democratic space - even more so than it had been during the "golden age" of Athens.

\section{Beginning the Transformation: Responding to The Four Hundred}

The reign of the Four Hundred was short but memorable with lasting effects on Athenian self-conceptions of democracy. Following the desecration of the herms and the subsequent failure of the Sicilian expedition in 415, the Athenians, desperate to remedy a losing war against the Spartans, began to lose faith in their constitution. In short, both Thucydides and the author of the Athenian Constitution recount a narrative in which a group of oligarchic conspirators held an assembly in Kolonos, about a mile outside of the city - most likely to discourage attendance - where they voted to dissolve the existing democratic institutions (Athenian Constitution 29-33; Thucydides 8.47-98). ${ }^{224}$ The subsequent reign of The Four Hundred was short and marked by failure; upon the loss of a naval battle at Eretria and the Euboean revolt, the demos quickly ceded the power of the Four Hundred to Athenian citizens who possessed arms, otherwise known as "The Five Thousand" and eventually, to the rest of the demos (Athenian Constitution, 33). However, in spite of the short and unsuccessful reign of The Four Hundred, the fact that they assumed power constitutionally was still a heavy blow to the democracy. More than that, the Four Hundred had brandished the Athenian patrios politeia (ancestral constitution) as an anti-democratic weapon, arguing that "hos ou demotiken alla paraplesian ousan ten Kleisthenous politeian tei Solonos" (the constitution of Kleisthenes was not democratic but more like Solon's) (Athenian Constitution, 29.3-4). ${ }^{225}$ The number Four

\footnotetext{
${ }^{224}$ Stem, (2003), 31.

225 Shear, (2011), 16.
} 
Hundred was likely an attempt to fashion themselves after the original Solonian boule. Therefore, the restored democracy following the Four Hundred had to once again lay claim to their own past in order to re-legitimise democratic rule and recover the Athenian democratic identity, lest it be overthrown from within so easily again.

The Athenian democrats not only had to reconcile the question of how to make Athens democratic again, but also, whether it was possible to re-establish a continuum of Athenian democracy given that their foray into oligarchy on the basis of the patrios politeia was so recent. ${ }^{226}$ One answer was the monumentalisation of epigraphy. Following the deposition of The Four Hundred, the Athenians needed to make universally clear their ancestral laws so that there was no ambiguity surrounding whether their patrios politeia had been democratic. ${ }^{227}$ Although these laws had been documented, they were lacking in both standardisation and centralisation - meaning that they had been scattered across Athens and inscribed on a smattering of materials from wood to bronze to poros altars. ${ }^{228}$ Thus, it is safe to assume that part of the ease with which The Four Hundred assumed the patrios politeia was due to a lack of accessibility to these documents, which had made them flexible to interpretation.

In response to this issue, the Athenians dispatched a special commission of what was known as anagrapheis (recorders). ${ }^{229}$ According to an almost fully preserved Pentelic marble stele of Drakon's law on homicide dated to 409/8, their role was to "anagra[ph]sa[n]ton" (publish) the laws, "ton nomon paralabontes para to b[a]s[i]le[os]...stelei lithinei...[pros]the[n] tes stoas tes basileias" (on a stone stele in front of the Stoa Basileus, after acquiring them from the Basileus) (IG I ${ }^{2}$ 115.5-7). ${ }^{230}$ Other evidence for this endeavour comes from Lysias' Against Nikomakhos, in which the accused is tasked with "anagrapsai tous nomous tous Solonos" (recording the laws of Solon) (30.2). While the wording of "paralabontes para to basileos" is ambiguous, Stroud offers two solutions. Either the anagrapheis were to take the laws from within the Stoa Basileus, where kyrbeis and axones of the laws may have been kept but inaccessible due to their Archaic format - which would set a precedent for the placement of the laws in front of the Stoa Basileus - or that it was the role of the Archon Basileus to walk

\footnotetext{
${ }^{226}$ Shear, (2011), 16.

${ }^{227}$ Stroud, (1968), 24.

${ }^{228}$ Stroud, (1968), 24.

229 Stroud, (1968), 24.

${ }^{230}$ Incidentally, also the earliest surviving mention of the Stoa Basileus (Stroud, (1968), 30).
} 
around the city and collect the laws for the anagrapheis to inscribe. ${ }^{231}$ Either way, the implication here is that the anagrapheis were expected to make copies of the Athenian laws and monumentalise them in one place, as opposed to revise potentially antiquated laws which had , at that point, already been replaced. ${ }^{232}$

Once again, space and monument stand at the forefront of the conversation two reasons. Firstly, there is an element of practicality to the re-inscription of laws; their centralisation in the agora and their ostentatious appearance in stone would have been a self-asserting presence to the citizens who frequented the space - eliminating the air of mystery surrounding the sources. However, there remains contention as to whether or not these stelai were ever intended for public reading, considering the literacy of the average citizen as well as the visibility of the lettering. ${ }^{233}$ Regardless of whether or not the stelai were meant to be read, the fact that they were visually impressive is undeniable. This is especially so if one considers the sheer volume that would have been in the agora, further suggested by Lysias in Against Nikomakhos when he accused the anagrapheus of stretching out his four month appointment for over six years, when the more likely reality was that four months was not enough time to complete the task given the sheer volume of Athenain law to consolidate (30.2). ${ }^{234}$ Moreover, Shear observes that prior to the commission of the anagrapheis, the only inscriptions found in the agora were copies of those already found on the Akropolis placed before the Old Bouleuterion. Therefore, the re-inscription of laws concentrated at the Stoa Basileus - a more versatile and accessible building than the Bouleuterion - would have stood out through novelty. ${ }^{235}$ Finally, not only was the marble upon which the law of Drakon had been inscribed extra fine, so too was the lettering of the scribe, indicating the amount of money - and by extension, importance - dedicated to the project. ${ }^{236}$

Even if the stelai were not meant to be read, they were meant to be seen, and in being seen, to assert a message of Athenian democratic strength rooted in the strength of the polis' legal institutions. The connection between the democratic re-inscription of law and the Four Hundred is clear in recent memory, seeing as the oligarchs had usurped the democracy through

\footnotetext{
${ }^{231}$ Stroud, (1988), 29; Wolpert, (2002), 37.

${ }^{232}$ Meyer, (2013), 454; Stroud, (1968), 24.

${ }^{233}$ Shear, (2011), 15.

${ }^{234}$ Stroud, (1968), 25

235 Shear, (2007), 97.

236 Stroud, (1968), 4.
} 
legitimate means, taking advantage of the confusion. Clarification of these same laws then, delegitimises the claims that the patrios politeia of Athens had been undemocratic on the basis that the Four Hundred had simply misinterpreted them. Seeing as the Four Hundred never monumentalised their interpretation - or to speculate, had their monuments taken down - the democratic polis could take advantage of the same set of opaque and inaccessible laws in the same way as their political opponents, yet do so with the advantage of permanence and proof inherent in marble. The connection between the democrats and the re-inscription is most evident considering the first words of the Drakon stele - "edokhsen tei boulei kai toi demoi" (granted by the boule and the demos) - the two most important institutions of the democracy lending legitimacy to a third: the law. Like most monuments and lieux de mémoire in the context of the Athenian Agora, these inscriptions establish a connection with the past, and in doing so, constructs and reminds the contemporary Athenians of their constitution's legitimacy, while ensuring that this assertion remains for the future through its physical presence.

Similarly, the restored democracy quickly reasserted themselves over the few buildings that had become connected to the Four Hundred. According to Thucydides, one of the first acts of The Four Hundred was to appear "bouletutais ousin en toi bouleuterioi" (to the councillors in the Bouleuterion) and pay them for their compliance, after which "he te boule ouden anteipousa hupexelthe" (the boule left without speaking) (8.69-70). Not only that, but the Four Hundred themselves proceeded to enter Old Bouleuterion and perform the civic and religious duties of the boule (70.1). The scene of The Four Hundred "eiselthontes eis to bouleuterion erkhon tes poleos" (entering into the Bouleuterion and ruling over the polis) makes an appearance also in the Athenian Constitution, with the physical act of them entering the Old Bouleuterion highlighted again (Athenian Constitution, 32.3), explicably linking the government of The Four Hundred with the symbolic takeover of the building. In the historical tradition at the vey least, the Old Bouleuterion is a lieu de mémoire for the oligarchy's usurping of a spineless Athenian boule, and given the likelihood of its transition into the Metroon after the rule of the Four Hundred as well as the Athenians' conscious manipulation of space to suit their own narrative, it would not be absurd to connect the two events. 
As Loraux argues, simply removing something does not make it disappear; it would be conspicuous by its absence. ${ }^{237}$ It is not difficult to imagine why removing the Old Bouleuterion entirely would be problematic, considering its history of civic function and its connections to a former Peisistratid domain. At the same time, the recent history of The Four Hundred and the desperation with which the restored democrats wanted to re-establish a narrative of continuous democracy in recent memory meant that a place that had been so tainted by not only the operations of The Four Hundred, but also the compliance of a major democratic institution could not stand as was. Therefore, the Old Bouleuterion transformed into the Metroon sometime contemporary with the building of the New Bouleuterion, and its purpose transformed from an administrative centre into a storage archive for written laws and decrees - most of which had been written on perishable materials. ${ }^{238}$ In doing so, the presence of the Four Hundred in the space of the Old Bouleuterion had been replaced by physical presence the very laws they usurped, symbolically defeating the memory of democracy's constitutional downfall with the permanence of the recorded law.

On the other hand, the administrative role of the Old Bouleuterion had been replaced with a new building entirely. Sometime between 415 and 406 BC - most likely following the deposition of The Four Hundred - the New Bouleuterion was constructed right next to the older building. Although the two buildings enforced continuity of constitutions through their spatial proximity, it was a new structure entirely devoid of undemocratic associations. Moreover, the New Bouleuterion seemed to be a space completely open to the public eye - evident in Xenophon's account of Kritias who intimidated the boule by lining "tois druphaktois" (the fences) of the New Bouleuterion with armed men "phaneros tei boulei" (in plain sight of the boule) (Hellenika, 2.3.51). Whether or not this was a departure from the Old Bouleuterion is uncertain, but given that the Metroon housed perishable documents, the older structure most likely accommodated for spaces sectioned off from the public whereas the New Bouleuterion seemed to do no such thing. Shear thinks that this is a deliberate attempt at transparency and a subversion of recent events: a new boule could no longer operate in secret and was held accountable by nature of the building they occupied - a symbolic space that would in no way allow conspirators to vote out the democracy while hidden from the public. ${ }^{239}$ For those living in recent memory of The Four Hundred, such symbolism is a promise for the future stability of

${ }^{237}$ Loraux, (2000), 188.

238 Shear, (2011), 84.

${ }^{239}$ Shear, (2011), 120. 
the democracy; for subsequent Athenian generations, the change in Bouleuteria wipes yet another trace of The Four Hundred away from the agora.

Alongside these unprecedented changes to the agora, the restored democracy also turned to existing monuments in order to refashion the brief episode of oligarchy: namely, the Tyrannicides. Mitchell argues that as early as the $5^{\text {th }}$ century, the historical tradition had already dismissed tyranny as a viable form of government. The tyrant was instead, stereotyped to create an ideological opposition to good leadership, and often depicted as a morally decrepit figure driven to rule outside the confines of law by their own greed and selfishness - most prominent in Herodotos' characterisation of the rule of one in the Persian constitutional debate (3.80.46). ${ }^{240}$ The spectrum of undefined constitutional forms which existed at the time of Greek poleis became easier to understand via their relationship to tyranny, since the concept of tyranny itself could always remain a clear fixed point against more nuanced political affiliations. ${ }^{241}$ Therefore, although it is an easy argument to assume that the demonization of tyrants in Athens began as a result of the political turmoil at the end of the $5^{\text {th }}$ century so as to vilify oligarchy, Mitchell's argument that there was a history to the antagonism of tyranny is more convincing - especially considering the Athenian self-imposed narrative of the Peisistratid period. ${ }^{242}$

What is more likely then, is that the recent oligarchy of The Four Hundred was refashioned into a multi-faceted tyranny so as to make the triumph of democracy a clear and objective good. Instead of an episode wherein the Athenians sought out a legitimate alternative to democracy in a time of desperation which resulted in the rule of The Four Hundred, The Four Hundred were branded as tyrants who sought to usurp the legitimate Athenian constitution. Again, this reaction delegitimises their claim to the patrios politeia which could in no way belong to tyranny, while recasting the claim in itself as an immoral attempt at ruling outside of existing laws and institutions: a much more preferable narrative to the democracy being used to destroy itself. Moreover, by conceiving of The Four Hundred as tyrants, the Athenian democrats strengthened their own claim to the law as well as their actions to monumentalise them, since the stelai themselves stood as reminders that the Athenian laws were permanent fixtures in the civic space of the agora. These laws, in conjunction with the Tyrannicide sculptures that stood

\footnotetext{
${ }^{240}$ Mitchell, (2006), 179.

${ }^{241}$ Mitchell, (2006), 178.

${ }^{242}$ Mitchell, (2006), 183.
} 
in view of the Stoa Basileus sent the overwhelming message that the agora, and by extension Athens, was no place for tyrants.

The conflation between The Four Hundred and tyranny is most obvious in the decree of Demophantos. Although this monument does not survive, it is quoted in its entirety by Andokides in On the Mysteries. The stele on which the decree survives seems to cover two subjects. First is the decree itself, which states that "ean tis demokratian katalue ten Athenesin...polemios esto Athenaion kai nepoinei tethnato" (if anyone overthrows the Athenian democracy then he will be an enemy to the Athenians, let him die with impunity) (1.96). Following this clause, the property of the deceased would be confiscated by the state and the killer of such an individual acquitted from murder (1.96). The stele then proceeds to spell out the oath that would be sworn by "athenaious hapantas" (all the Athenians) "pro Dionysion" (before the Dionysion) (1.96, 98). The wording of the oath itself is, for the most part, a repetition of the decree with a few notable differences. Firstly, it starts with "ktano" (I will kill) (1.97), thereby framing itself within the context of personal agency so that the oath is both something adhered to by the collective citizenry, but also a promise made on a personal level. Arguably, the transition of individual power to the collective is the essence of Athenian democracy, and this process embodies that.

Secondly, the oath makes clear the link between an overthrower of democracy and a tyrant. While the first lines specify that the decree of Demophantos concern those who overthrow democracy, tyranny is conspicuous by its absence. Instead, the perpetrator is only described as someone who "arkhen tina arkhei katalelumenes tes demokratias" (assumes any office after the overthrow of democracy) (1.96). It is only in the oath itself when this notion expands to include those who "turannein epanastei e tou turannon sugkatastesei" (establishes either himself or another as a tyrant) (1.97). Moreover, the Athenian goes to swear that he will honour the killer and their children "kathaper Harmodion te kai Aristogeitona kai tous apogonous" (like Harmodios, Aristogeiton, and those from their kin) (1.98). Thus, the decree's purpose to encourage tyrannicide is clear - calling upon the Athenians to emulate the men honoured in the agora as the ideal Athenian citizens based on the polis' ancestral history. Yet, the fact that both the stele and the oath start not with tyranny but merely those who assume office after the overthrow of "demokratia" is significant, especially considering that the decree of Demophantos seems to be the earliest piece of legislation passed following the rule of The Four 
Hundred. ${ }^{243}$ What seems to be the case is the deliberate conflation of oligarchy and tyranny as a response to recent historical events. In using the rhetoric of tyranny, the restored democracy only strengthens the force of their claim to government while further reinforcing that democracy was the only legitimate constitution for Athens. The tyrant had been the enemy of the demos, but the decree of Demophantos makes it so that the concept of "tyrant" encompasses any undemocratic constitution - retroactively dismantling The Four Hundred while asserting the permanence of Athenian democracy for the future. ${ }^{244}$

The monumentalisation of the decree of Demophantos reinforces the strength of its meaning. Firstly, the fact that it included both the decree and the oath sworn by the Athenians creates interesting connections between the present and the future. If the decree reflects reality, and all Athenians did indeed swear this oath, then the monumental stele becomes a lieu de mémoire for the ritual oath-swearing of the demos. Therefore, each time a citizen saw the stele, it would remind them of their own promise to kill as well as the memory of the Athenian collective coming together and swearing against opponents of the demos. It is this memory, Teegarden argues, that spurs some Athenians into motion against The Thirty, since implicit within it is the promise that resistance against tyranny was part of the Athenian collective identity. ${ }^{245}$ Whether or not his first assertion is correct, the connection between monument, memory, and collective identity is certainly present. Each time an Athenian reads the stele, they would not only relive the memory of the oath swearing but also re-enact part of that ritual via the inclusion of the oath itself, thus strengthening the force of that memory and commitment to democratic Athens and leaving it for subsequent generations also. ${ }^{246}$ Therefore, the memory of tyrannicide is permanently left alive in the collective consciousness of Athens.

The positioning of the stele in the visual context of the agora is also especially notable. Andokides calls it the stele "emprosthen esti tou bouleuterios" (in front of the Bouleuterion) (1.95), most likely referring to the open air space of the New Bouleuterion given the dramatic dating of the speech. ${ }^{247}$ This, in isolation, is a powerful placement given its proximity to the civic centre of Athens, as well as the boule who would operate in its presence. It is a double-edged reminder, on the one hand incentivising the boule and demos of Athens to assume the

\footnotetext{
243 Teegarden, (2014), 30.

${ }^{244}$ Shear, (2007), 158.

245 Teegarden, (2014), 16.

246 Shear, (2007), 158-159.

247399 BC: the date of Andokides' trial.
} 
role of the tyrannicide and ideal citizen of Athens, should the occasion arise, with the promise of wealth and honours. On the flipside, the stele also acts as a deterrent, threatening the boule via its proximity with the fate of those who dare to conspire against the democratic polis - acting as a check on the potentially overzealous ambitions of the administration. Expanding outwards, the decree of Demophantos is linked to the other laws of the re-inscription project, as the Stoa Basileus and the New Bouleuterion sit on the same street to the west of the agora (Fig. 1). Moreover, it is directly opposite the Tyrannicide sculptural group in the middle of the agora, a mere 95 metres away. ${ }^{248}$ The spatial relationship once again reinforces the connection between undemocratic constitutions and tyranny, and the two monuments engage in a visual dialogue of Athenian self-fashioned identity - one in which democracy has always been the norm, and of the inevitability that a good citizens would rise up against it.

This process of refashioning the Four Hundred to fit a narrative of tyrannical opposition to Athenian democracy was aided by a historical coincidence. According to Thucydides, Phrynikhos, one of the members of The Four Hundred, was stabbed to death in the agora by two men - one of whom died in the act while the other was tortured unsuccessfully for information (8.92.1-2). The event itself as recorded in history is extremely similar to the case of Harmodios and Aristogeiton, from its spontaneity to the location and even to the fates of the two attackers; likely owing to the way in which the Athenians chose to commemorate and remember the event. For instance, Lysias claims that "ho Phrynikhos gar houtos tous tetrakosious katestesen; epeide d'ekeinosapethanen, hoi polloi ton tetrakosion ephugon" (Phrynikos established The Four Hundred, and after he died many of the four hundred fled) (13.73-74).

However, neither of Lysias' claims seem to be true. Phrynikhos makes no appearance in either Thucydides or the Athenian Constitution when they describe the conspiracy of The Four Hundred, with Thucydides noting that his murder only incited the oligarchs to action (Athenian Constitution, 32.2; Thucydides, 8.68.2, 8.92.4). Moreover, Phrynikhos seemed to have suffered a posthumous character assassination; in Plutarch's Life of Alcibiades we learn that he was tried after death, declared as a traitor, with his house razed to the ground and bones cast out from Attika (25.10). ${ }^{249}$ Phrynikhos' importance to the Four Hundred then, seems to have been

\footnotetext{
${ }^{248}$ Shear, (2007), 152.

${ }^{249}$ Azoulay. (2017), 63.
} 
overblown even more so than Hippias' importance to the Peisistratids. Moreover, both Plutarch and Thucydides mention that his assassins had received honours from the restored demos most likely the same ones promised in the decree of Demophantos to the extent of Harmodios, Aristogeition, and their kin. Not only does this punctuate the similarities between the assassination of Phrynikhos and Hipparkhos, but it sets a precedent that the demos will deliver on tyrannicide as well as its rewards while also establishing a continuity of tyrannicide as the typical response to the absence of democracy.

Finally, the location of Phrynikhos' death in relation to the stele of the decree of Demophantos is interesting. If Thucydides' account is correct, then Phrynikos was stabbed "apo tou bouleuteriou apelthon" (after leaving the Bouleuterion) (8.92.1). Not only is this location extremely close to the Leokorion where Hippias was murdered, but it would also be the same place the decree of Demophantos was erected. ${ }^{250}$ The stele then, implicitly commemorates this instance of "tyrannicide" - something even more significant upon considering that the Tyrannicide sculptural group were most likely erected next to the Leokorion where Hipparkhos was murdered. The similarities between the Phrynikos incident and the murder of Hipparkhos down to even the way in which they were monumentalised are too many to ignore, and the history of the Tyrannicide sculptures as a lieu de mémoire imbues the stele of the Demophantos decree with the same level of clout, while the Demophantos decree contributes a new layer of specificity and Athenian accountability to the sculptures through the enacting of ritual. These monuments and their contribution to the Athenian democratic narrative would prove to be instrumental to the recovery of the polis from the reign of The Thirty.

\section{The Thirty: Deconstructing the Democracy through the Reconstruction of Space}

Unfortunately for the recently restored democracy, the Athenian constitution would once again be shaken following Sparta's victory in the Peloponnesian War. Although this period is one of the most well documented in ancient historical sources, it is also one of the most nebulous - with a multitude of sources unable to agree on neither the nature nor the sequence of events which occurred. ${ }^{251}$ Yet, almost as a direct contradiction to this statement, it is also a period marked by the reconciliatory powers of Athens which on the surface owes itself to a successful

250 Azoulay, (2017), 62.

${ }^{251}$ Stem, (2003), 18. 
forgetting of the rule of The Thirty and the stasis that occurred. The preceding arguments have demonstrated that the Athenians were able to utilise selective memory to fashion their own collective identity and were at the very least, aware of the contributions place and monument made to these constructions. Therefore, the argument that the Athenians simply "forgot" about the trauma they had suffered is hardly believable. Instead, just as they had done so in the past, it was an extension of selective remembering and the refashioning of Athenian identity that enabled them to reconcile the difficulties in their own history and community.

I will not attempt here to dissect the history of The Thirty, but only to provide a brief narrative summary of their rule for the purpose of context. During the archonship of Pythodoros in 404/3 BC, most likely in the late summer of 404 BC, a group of thirty oligarchs assumed power of Athens by force of Lysander, the Spartan king (Athenian Constitution 35.1; Xenophon, Hellenika, 2.3.2). ${ }^{252}$ Over the next thirteen months, these thirty men would tear down the long walls of Athens, install a Spartan garrison in the city, and disenfranchise and exile all but three thousand Athenian citizens. ${ }^{253}$ Most heinously, they would execute their opponents without trial under the pretence of purging the city of unjust men - both real and imagined - and at times merely for the sake of confiscating the property of the wealthy (Lysias, 12.5; Athenian Constitution, 35.3). By the end of their reign, they had executed around 1500 citizens (Athenian Constitution, 35.4). ${ }^{254}$ These actions were universally received as negative by ancient sources which fashion The Thirty as morally bankrupt individuals with no method to their madness. ${ }^{255}$ However, in recent scholarship Wolpert makes the more convincing argument that the violence of The Thirty had been an attempt to reconfigure the political landscape of Athens from one of a broad democracy entrenched within Athenian identity to a narrow oligarchy. ${ }^{256}$ Therefore, the widespread terror they had ushered in for the Athenians was a systematic attempt at breaking down their self-conception of democracy by conditioning the demos through violence so that The Thirty could refashion the Athenian constitution in a way that The Four Hundred could not. ${ }^{257}$

\footnotetext{
252 Stem, (2003), 18, 23.

${ }^{253}$ See Krentz, MacDowell, Wolpert, Shear, Stem, Ober, Carawan, among others.

${ }^{254}$ Cohen, (2001), 337. Gehrke, in his comprehensive survey on stasis posits $20 \%$ of the citizenry as the mean death toll for Greek civil conflict in the $5^{\text {th }}$ and $4^{\text {th }}$ centuries $((1985), 236)$. Of course, none of these estimates include the likes of metics, women, and slaves.

255 Wolpert, (2006), 213.

256 Wolpert, (2006), 214.

${ }^{257}$ Wolpert, (2006), 221.
} 
Wolpert's assertions resonate particularly with an examination of the changes The Thirty had made to the landscape of Athens and the agora. Unlike the Four Hundred before them who had failed to leave a physical remnant, The Thirty seemed to prioritise the assumption of existing spaces and the manipulation of monumentalisation. Most famous is Plutarch's claim that they had reoriented the Pnyx to look towards an oligarchic city as opposed to a democratic sea (Life of Themistokles, 19.4). Although the archaeological sources corroborate this evidence with the Pnyx indeed having been turned around the end of the $5^{\text {th }}$ century, whether the action was ideologically motivated cannot be proved. ${ }^{258}$ At the same time, we should not ignore the fact that Plutarch attributes ideological motivations to The Thirty's changes to space, since it demonstrates, at the very least, awareness that the two are intrinsically linked. Shifts in space should, therefore, not be ignored.

A less famous but more significant example would be The Thirty's treatment of law and monuments of legislation. One of the most consistently emphasized traits of The Thirty was their utter disrespect towards Athenian law and legal procedure, with some of their first actions being to remove the radical democratic reforms of Ephialtes from the Areopagos, revoke and remove several proxenoi decrees from the Akropolis, and to neuter the power of the jury while performing their own mock trials with predetermined outcomes (Athenian Constitution, 35.2). ${ }^{259}$ These actions make more sense when considered alongside Wolpert's argument of systematic deconstruction, as well as the importance of legislation to the restoration of the democracy following the events of $411 \mathrm{BC}$ - doubtless to be still fresh in recent memory. In terms of evidence, both Fingarette and Shear make a convincing case regarding fragments of a so-called "Wall of Nikomakhos" consisting of thirteen fragments excavated from the agora. These fragments are curious, in that some were inscribed on both sides with a sacrificial calendar in Ionic lettering on the obverse and a naval law in Attic lettering on the reverse, with some having reverse sides either smoothed over to suggest erasure, or polished to suggest an absence of inscription. ${ }^{260}$ Not only do Fingarette and Shear attribute these inscriptions to the two periods of the anagrapheis commission with the Attic lettering corresponding to the postFour Hundred effort and the Ionic lettering post-Thirty, but they propose that the evidence of erasure on the reverse side can be attributed to The Thirty themselves.

\footnotetext{
${ }^{258}$ For instance, Thompson and Wycherley suggest that the Pnyx was reoriented to protect the ekklesia from the northeastern winds $(1972,45)$.

${ }^{259}$ Wolpert, (2002), 34.

${ }^{260}$ Fingarette, (1971), 333; Shear, (2011), 80-82.
} 
In addition to the Athenian Constitution which notes that The Thirty did indeed remove monuments of legislation, two sources support these claims. Firstly, in Lysias' Against Nikomakhos, after the orator shames the anagrapheus for extending his four-month post to six and a half years, he claims that the way Nikomakhos was able to do so was by "tous men enegrafe tous de exeleiphen" (engraving some stuff but erasing others) in a manner similar to Penelope in Homer's Odyssey (30.2). Yet unlike the Homeric suitors who were negligent to the point of stupidity for the sake of plot, it is unlikely that the real life Nikomakhos and the other anagrapheis would have been allowed to prolong their post in such a way under the rule of The Thirty - which elapsed during this period of almost seven years. Therefore, instead of the commission being merely interrupted between 404 and 403, it is likely that The Thirty took over and advised that the anagrapheis erase what had been inscribed - initially as a subversion of the democratic commission and then to use the same stelai for their own laws. Lysias' accusation was probably a malicious spin on the truth for the sake of rhetoric since he conveniently leaves out the Athenian struggles contemporary with Nikomakhos' supposed inadequacy. ${ }^{261}$ Moreover, this is the interpretation which best explains one of Andokides' statements made in passing, since he mentions that for those "skopein toi boulomenoi" (wanting to look at them), the laws were inscribed in the Stoa Basileus "per proteron an egraphesan" (where they had been inscribed before) (1.84). Given that the effort to consolidate Athenian laws at the Stoa Basileus for the sake of access was a recent effort in response to The Four Hundred, this is most likely the "per proteron" to which he refers - implicitly recalling a period after when the laws were no longer there.

In addition to the mockery and erasure of the liéux de memoire relating to democratic legal institutions, The Thirty worked quickly to occupy other important spaces in the agora. Unsurprisingly, they took up seats in the New Bouleuterion (Lysias, 8.37); an act that would doubtless have been more insulting to the Athenians considering their recent repurposing of that space. However, The Thirty did not stop there, and spread their occupation to the entirety of the arkheia district. We are told that they summoned Sokrates, among others, "eis ten tholon" (to the Tholos) so as to order the execution of Leon (Plato, Apology, 32d). They also seemed to have operated out of the Stoa Poikile, with Diogenes Laertius claiming that it was the place where "tois triakonta ton politon pros tois khiliois tetrakosioi aneirent'en autoi" (one thousand and four

${ }^{261}$ Shear, (2011), 83. 
hundred citizens were done away with by The Thirty," and Wycherley suggests that the force of "anairo" here almost certainly implies that the citizens were sentenced to death. ${ }^{262}$ The general space of the agora itself was also not safe: Demosthenes mentions the arrests that had transpired there in passing $(22.52,24.164)$, while the arrest and execution of Theramenes - perhaps the most heinous act committed by The Thirty - is accompanied by a vivid description of the man being dragged from the hearth of the New Bouleuterion, screaming as he is taken across the agora (Xenophon, Hellenika, 2.3.50-56). Therefore, it seemed that The Thirty did not merely operate out of the agora, but they had taken over the space as the primary domain of their rule - spitting in the face of the narrative of democracy so entrenched in the space by repurposing buildings, erasing inscriptions, and desecrating it with violence. ${ }^{263}$ Although the rule of The Thirty lasted only a little over a year, their damage to the space had been notable, informing many of the changes made to the agora in their aftermath.

Concurrent to the dismantling of the Athenian democracy, a band of exiles, metics, and other miscellaneous men had gathered at Phyle with Thrasyboulos as their leader. Eventually this band overcame The Thirty and their supporters at the Battle of Mounikhia, retaking Pieraieus and thereby forcing the Spartans to abandon their support of The Thirty and renegotiate peace with a democratic Athens. ${ }^{264}$ At some disputed point in time after the negotiation, ${ }^{265}$ the Athenians swore an oath, the wording of which is once again preserved in Andokides' On the Mysteries: “kai ou mnesikakeso ton politon oudeni plen ton triakonta kai ton deka kai ton endeka; oude touton hos an ethelei euthunas didonai tes arches hes erxen" (I will not recall badly about anyone except The Thirty, The Ten, and The Eleven, and not even any of them if they are willing to undergo an audit for offices) (1.90). ${ }^{266}$ The swearing of this oath became the much lauded "Athenian Amnesty" to which the success of Athenian reconciliation post-stasis was attributed. As Ober articulates, the oath was a ritual "to encourage official forgetfulness

\footnotetext{
${ }^{262}$ Wycherley, (1957), 36.

${ }^{263}$ We do not know what happened to the Tyrannicide sculptures during this period. Although they were not destroyed, Azoulay suggests that small modifications - such as the removal of their weaponry - were made to symbolically take away their power, and by extension, the power of the demos. The precedent for this is the case of Philites - a tyrannicide who was commemorated in Erythrae with a statue brandishing a sword. When oligarchs briefly assumed power, they had removed the sword from his hand, which was later restored upon the democrats' resumption of power $(2017,67)$. While this would make sense for the Tyrannicides, it is impossible to know whether or not The Thirty treated the sculptures in the same way.

${ }^{264}$ Cohen, (2001), 337; Middleton, (1982), 298.

${ }^{265}$ Xenophon attributes the swearing of this oath to after the breakup of the state at Eleusis to which most of The Thirty and their associates had fled, most likely around $401 \mathrm{BC}$ (Hellenika, 2.4.43). On the other hand, the Athenian Constitution is more specific, dating the amnesty to the archonship of Eukleides in 403/2 immediately after the restoration of the democratic polis (39.6). See Chapter One for further discussion on this point. 266 The Ten and The Eleven refer to The Thirty's board of magistrates in the city and in Pieraieus respectively.
} 
about the stark divisions that had been revealed in the course of civil conflict" in order to reassert a sense of lost political unity. ${ }^{267}$ These oaths did not seem to be safeguarded by legislation, but by the deterrent of divine vengeance and the promise of good citizens who would want to put the harmony of the state before their individual enmities. ${ }^{268}$

It does not take a genius to recognise these as flimsy reasons to adhere to the oath, especially following a period of mass violence, trauma, and humiliation. As Gehrke argues, the atmosphere of mistrust following stasis is not so easily remedied by oath, and this is particularly applicable to Athens for three reasons. ${ }^{269}$ Firstly, the Athenians had limited ways of dealing with grievances, and vengeance through the legal system often seemed to be the only answer. Avenging the death of a loved one was not only encouraged but expected of surviving kin lest they become impious and dishonourable, seeing as kin were the only ones able to take homicide trials to court. ${ }^{270}$ Secondly, three thousand citizens had remained in Athens as allies of The Thirty, and Thrasyboulos' forces were overwhelmingly thin with Athenian citizens only comprising a small percentage of it. ${ }^{271}$ This implies that even in the case of exiled Athenians, most had acted as accomplices to The Thirty at worst, and complicit bystanders at best - hardly emulating the ideal of tyrannicide. Finally, forgetting is not something that can be done on command, and the swearing of an oath to not remember is a memory in and of itself - a collective memory that all the Athenians now shared. This is not to mention that the Athenian Agora had been tainted with memories of violence on a level unprecedented for the Athenians; even if the demos did make a concentrated effort to forget, merely stepping foot in the agora would once again trigger these memories.

Therefore, it is unsurprising that the failure of the amnesty itself is well documented. The Athenian Constitution claims that the amnesty was successful after a magistrate named Arkhinos convinced the boule to make an example of an individual who had contravened the amnesty by executing him. After this incident "oudeis popote husteron emnesikakesen" (nobody ever recalled bad things again), with the Athenians exhibiting the "kallista de kai politikotata hapanthon kai idiai kai koinei" (most beautiful and stately behaviour of everyone in both public and private) (40.2). This seems to be a complete embellishment of the truth on

\footnotetext{
267 Ober, (2005c), 91.

268 Dorjahn, (1946), 35.

${ }^{269}$ Gehrke, (1985), 283.

${ }^{270}$ Cohen, (2001), 338-339.

${ }^{271}$ Krentz, (1982), 83-84.
} 
the part of the author. While it is true that the Athenians did not pursue direct legal action against each other for what happened during the period of The Thirty and stasis, the rhetorical landscape of the $4^{\text {th }}$ century was littered with references to The Thirty. More specifically, what a person did during the rule of The Thirty became a rhetorical trope of character evaluation. ${ }^{272}$ A person's exile during that time could either be used as praise to defend their unwillingness to support The Thirty, or as slander to shame the same individual for not staying and fighting for the demos.

Perhaps the best illustration of the dichotomy between the oath to not remember and the remembering that occurred takes place in Andokides' On the Mysteries. Moments after he implores the people to remember their oath, he launches a scathing attack against Meletos for his arrest of Leon and Epikhares for serving on the boule of The Thirty (1.90, 94-95). In fact, Andokides' attack on the latter is what spurs a reading of the decree of Demophantos verbatim, since he argues that Epikhares should be killed accordingly (1.95). The trope became so ingrained in oratory that even twenty years after the fact, Isokrates brings up that although Lokhites was too young to have aided The Thirty, he was morally bankrupt in such a way that he would have helped them had he been old enough (20.10-11). Therefore, the memory of The Thirty was very much kept alive to be wielded as a weapon in court, and the fact that the tropes were so pervasive is evidence of their effectiveness. Since the outcome of a trial depends on the vote of the jury, these judgements based within stasis would have most likely appealed to common shared grievances and enmity floating in the consciousness at the time, indicating that the Athenians remained emotional about these events that have not been left forgotten. While the Athenian Constitution's story of Arkhinos is unlikely, we do learn from Isokrates that Arkhinos had passed a paragraphe (amendment clause) to strengthen the amnesty, introducing a fine for cases in violation of the amnesty if the accuser were to lose (Isokrates, 18.3). The fact that he felt the need to do this, in conjunction with the legal evidence recalling the stasis suggests that the law courts were a place where individuals could air their grievances to the public - something which occurred so frequently that it needed to be put in check.

Seeing as there was no real threat to the recent memory of stasis, we must then examine the ways in which the Athenians chose to monumentalise the space of the agora following the rule of The Thirty. Once again, the restored democracy worked to re-legitimise themselves, and

${ }^{272}$ Wolpert, (2002), 58. 
once again, they did so through law. The reasons for this are never outright stated, but could most likely be attributed to the precedent set recently in the aftermath of 411 , which was only exacerbated by The Thirty's disrespect towards the law during their reign. Legal terms were clarified, lawmakers were re-established, and the Athenians became obsessed with the anagrapheus commission - reflected in the sheer volume of inscriptions that found themselves in the agora after 403. According to Meyer, out of the two hundred and forty two Athenian decrees and laws found on inscriptions before 403/2, only thirteen of them concerned nonreligious matters. Following this period, however, Davies counts over three hundred accounts of stelai published for administrative and civic services alone. ${ }^{273}$ Given that the 411 commission of codification changed the primary location of civic inscriptions to the agora, it is safe to assume that once the commission resumed the trend continued, meaning that a majority of the various civic inscriptions found in the agora would have been a direct result of this project. This mass monumentalisation of law in an effort to reassert the agora as a democratic space was coupled by an increase in power to the legal system, thus establishing law as one of the fundamental facets of democracy and matching its commemoration as such. Not only did these inscriptions monumentalise the reestablished democracy, but they unequivocally differentiated the rule of the demos from the rule of The Thirty. ${ }^{274}$ Needless to say, the bastardisation of The Thirty in later evidence as lawless tyrants was most likely a result of the stake Athenians had placed in their legal institutions as an identifier of their commitment to demokratia.

Here, we must return to the Stoa Basileus as the main space in which these laws were erected. Archaeological and literary evidence both corroborate the assumption that the anagrapheis continued to erect laws in the vicinity of the Stoa Basileus just as they had in 411. The reinscription of Drakon's law on homicide places itself here, and gathering from the location of its scattered fragments, it is likely that the so-called "Wall of Nikomakhos" was found here too, matching Andokides' statement (1.84). The actual set up of the Stoa Basileus seemed to have been optimised to display as many laws as possible. A fire revealed that a wall of laws had been established across the stoa at the back of the building. ${ }^{275}$ Not only that, but two wings were built on either end of the building at the end of the $5^{\text {th }}$ century that made more room for displays. These wings took form of columnar porches, and opisthographic stelai were erected

\footnotetext{
${ }^{273}$ Meyer, (2013), 457.

${ }^{274}$ Cohen, (2001), 348.

275 Camp, (1986), 104.
} 
between the columns. ${ }^{276}$ Not only would this have been visually impressive, but it would also have interacted with existing democratic rituals. Recall that the front of the Stoa Basileus was the location at which the so-called lithos was placed, and it was at this lithos that archons, jurors, and witnesses swore oaths for the polis. ${ }^{277}$ Therefore, after the installation of these stelai, those who swore by the lithos would physically be flanked by the laws of Athens. ${ }^{278}$ On one hand, this is a powerful visual metaphor linking the longstanding institutions and people instrumental to the functioning of the democracy to the law, imbuing it with the same level of importance through association. On the other, the laws themselves now hold the oath-swearers accountable for their actions, acting as a reminder of their duties to the democracy. Given the conflation of Solon and his lawmaking with the Stoa Basileus in later sources, the newly founded association between legal institutions and the Athenian democracy was effective, and as recent memories of The Four Hundred and The Thirty fade, the assertion of the stelai that the law has always been, and will always be, indispensable to the Athenian democratic identity remains.

In addition to the legislative stelai, the Athenians also erected monuments commemorating the restoration of the democracy and honouring the men responsible. Two of these stelai were recovered from the agora, and both reflected terms according to the decree of Demophantos which promised to reward the recovery of democracy through violent action. The first of these is the Phyle stele (SEG XXVIII), which, according to Aiskhines was erected in the vicinity of the Metroon (3.187). This monument lists the name of the men from Phyle who, alongside Theozotides, liberated Athens from the "adikois thesmois" (unjust customs) of The Thirty. Moreover, the names were listed alongside both patronymics and demotics, emphasizing the Athenian nature of the men. It is interesting to note that another stele granting citizenship rights to the men from Phyle who fought on behalf of Thrasyboulos was also found, but on the Akropolis (IG II ${ }^{2} 10$ ). With that in mind, the effort to commemorate the men from Phyle in the agora seems to emphasize specifically the Athenian contribution to the victory. This is reinforced through its proximity to the exemplars of good citizens in the agora established by the Tyrannicide sculptures, the decree of Demophantos, and the law. ${ }^{279}$ Together, they send a

\footnotetext{
${ }^{276}$ Camp, (1986), 104.

277 Thompson, Wycherley, (1972), 88.

${ }^{278}$ Shear, (2011), 105; Thompson, Wycherley, (1972), 89.

${ }^{279}$ Shear, (2007), 107.
} 
message that the Athenian Agora is overwhelmingly the domain of the Athenian citizen, and the Athenian citizen is by nature, democratic.

A second stele known as the Decree of Theozotides concerns the orphans of stasis. Repurposed as a cover to the Great Drain in the agora, the decree - most likely contemporary with the Phyle commemoration - specifies that the children of "hoposoi athenaio[n] a[pethan]on [b]iaioi thanatoi en tei olig[arkhai b]o[eth]ontes tei demokratiai" (those Athenian men who died saving the democracy from the oligarchy by force) would receive one obol a day in the same way as orphans from external warfare (SEG XXVIII.45-46). This stele, once again, delivers on the promise of the decree of Demophantos and further blurs the distinction between the tyrant and the oligarch, with the two being used interchangeably when considering the wording of the two stelai in tandem. Not only that, but this particular commemoration blurs yet another boundary, that being the one between external and internal warfare. In celebrating the orphans of stasis in the same way as the orphans of war, the methods of reconciliation become clear: the Athenians no longer claimed ownership over The Thirty and their actions. Therefore, there was no longer any room for the Athenian citizen to be oligarchic, because to be an oligarchic was to be a tyrant, and to be a tyrant was a crime punishable by death. Retrospectively, this means that in Athenian memory, neither the Peisistratid tyranny nor the oligarchies of 411 and 403 were reflections of the Athenian polis, reinforcing the illusion that Athens and her citizens are intrinsically democratic.

Yet again, we circle back to the Tyrannicides and their sculptures. Although we do not know what happened to their monument during the rule of The Thirty, ceramic evidence suggests that Harmodios and Aristogeiton were honoured with increased vigour following the Athenian restoration. To be more specific, iconography featuring their sculptural group received a remarkable resurgence - particularly one instance where they featured on the shield of Athena on mass produced Panathenaic amphorae in $402 .{ }^{280}$ Not only that, but by 400 the Tyrannicides had become "impervious to attack," potentially due to legislation prohibiting the mockery of Harmodios and Aristogeiton passed after the democratic restoration. ${ }^{281}$ Moreover, Shear argues that although in the early $4^{\text {th }}$ century, some orators asserted their own ancestry as liberators of democracy as opposed to following the tyrannicide narrative - most likely as an extension of

\footnotetext{
280 Azoulay, (2017), 77.

281 Taylor, (1991), 97.
} 
the anti-oligarchic rhetorical tropes - these vanish within the next one hundred years. ${ }^{282}$ Shear suggests that this was the result of intensified rituals celebrating the Tyrannicides, possibly at the time of the Great Panathenaia, to strengthen the anti-tyrannical facet of Athenian identity. ${ }^{283}$ This suggestion would resonate also with the recent commemorations and honours endowed upon Athenian citizens in the agora, fashioning the democratic victory over The Thirty further into an instance of tyrannicide.

The connection between The Thirty and tyranny was easy to make, considering not only the violent nature of their actions, but also the treatment of oligarchy in 411 following The Four Hundred. That The Thirty disregarded the law was another happy coincidence for the Athenians - making it easy for their injustices to be overblown into stereotypically tyrannical proportions. ${ }^{284}$ Therefore, sometime during the $4^{\text {th }}$ century, The Thirty began to be known as "The Thirty Tyrants." 285 This conflation through subsequent memorialisations was crucial to the reconciliation of the Athenians in three ways. Firstly, by emphasizing the triumph of Athenian tyrannicide over The Thirty, the Athenians were able to create a scapegoat for the problems and losses they had suffered throughout the last decade. The Thirty became so reprehensible in the memory of the Athenians so that they could shoulder the blame for everything. From the trauma of violence and exile, to the humiliation of the Spartan garrison in Athens, to things only tangentially related to The Thirty such as the loss of the Long Walls. ${ }^{286}$ Moreover, by monumentalising and celebrating the victory of the democrats over The Thirty, the loss of the Peloponnesian War was overshadowed, giving the Athenians an excuse to avoid confronting their own failure. ${ }^{287}$

Secondly, by minimalizing the oligarchy into The Thirty and commemorating those directly responsible for their downfall, the complicit Athenian is conveniently passed over in silence. ${ }^{288}$ The fact that Thrasyboulos could not rely on the support of the Athenian demos and instead had to turn to foreign help was embarrassing, yet by spotlighting the Athenians who did participate with monuments in the agora this fact was also forgotten. Much like the myth of "internal resistance" woven by Germany following Nazi atrocities, the quiet Athenian could

\footnotetext{
282 Shear, (2012), 51.

283 Shear, (2012), 51.

${ }^{284}$ Cohen, (2001), 347.

285 Azoulay, (2017), 211; Krentz, (1982), 16.

286 Cohen, (2001), 348.

287 Cohen, (2001), 354.

288 Wolpert, (2006), 222.
} 
coast by on the illusion created by the monuments which perpetuated the narrative that one could be a democratic tyrannicide solely by virtue of being an Athenian citizen. ${ }^{289}$ Finally, as Carawan indicates, forgiveness was a concept invented by the Christians - meaning that the Greeks preferred anger as their outlet following a crisis. ${ }^{290}$ However, unresolved anger is poison to reconciliation, as it continues to fester if left unresolved. ${ }^{291}$ Seeing as the divisions between enemy and friend were not clear cut by the end of the stasis due to the question of complicity, Ober argues that the only way to express this anger was through tyrannicide. ${ }^{292}$ Thus, the commemorations of tyrannicide in the agora folds the collective identity of the ordinary passive Athenian citizen into the active agent of change. The popular memory of the event, then, would be one in which the Athenians collectively swung their dagger against The Thirty Tyrants: a much easier past to face than one of true stasis between legitimate citizens. However, the success of this constructed narrative was only possible due to its roots, both in the recent history of 411 and the ancestral narrative of Harmodios, Aristogeiton, and the Peisistratids. Therefore, the reincarnation of a democratic Athens would not have been so successful without the monuments in the agora reminding the Athenians of their own constructed identity.

\footnotetext{
${ }^{289}$ Cohen, (2001), 352.

${ }^{290}$ Carwan, (2013), 7.

${ }^{291}$ Loraux, (2012), 160.

292 Ober, (2005a), 225.
} 


\section{Conclusion}

Athens was a city of memory, and this was the result of deliberate manipulation on behalf of the demos - evidenced by an examination of the agora and its monuments. By the end of the $5^{\text {th }}$ century, the Athenian Agora had become a nexus embodying the revived democracy. On one hand, this was due to the active and concentrated effort the democrats made to spin a narrative of triumph in the face of tyranny - as if the democracy itself was never constitutionally threated by alternative systems of government. On the other, the strength of this narrative would not have been so potent if it were not for the wealth of monuments and memories already bound in the agora. In this sense, the Athenian Agora is an exemplar of interanimation and the lieu de mémoire. It is the embodiment of Ricœur's theories on the axes of memory, as the past never ceases to be a source of legitimacy for the Athenians, nor does it ever remain static and fixed in the present - always being influenced by whatever ideology was dominant at the time. The fact that literary sources - even the sceptical historians - all reflect aspects of these self-asserted narratives is evidence enough of their pervasiveness.

Conversely, an examination of the agora through the lens of memory theory also enables criticisms against the theories themselves. Nora was wrong to romanticise the practice of memory against the pursuit of history. The monuments and their associated rituals in the agora have demonstrated repeatedly over the course of the $5^{\text {th }}$ century that memory too, is just as dangerous a weapon for carving out a singular dominant narrative. At the same time, nor should the historical pursuit be privileged over memory. In terms of memory, there is nothing separating the contemporary scholar from the ancient Greeks. Just as it is a human instinct to yearn for the past, it is also human to try and make sense of it. Both history and memory are relics of these attempts to understand, and both are worthwhile avenues to pursue.

In the case of antiquity, where an objective truth is almost always inaccessible to us, it is more fulfilling to instead, try and understand the past according to the perception of the Athenians themselves - especially when it has profound consequences on their actions. If the reality of an event fades from collective memory, then surely it does not have the same impact as prevailing narratives. For instance, it is precisely these narratives which enabled the Athenians to reconcile after the trauma of stasis and the humiliation of defeat. Therefore, praise for the Athenian Amnesty is not a celebration of a successful mass forgetting, but the celebration of a 
century's worth of selective remembrance. This remembrance is rooted in the space of the agora, evidenced by its drastic transformation from a symbol of Peisistratid tyranny to a staunchly democratic civic space. By the beginning of the $4^{\text {th }}$ century the average Athenian citizen could no longer stroll through the agora without being confronted by his responsibility as a member of the demos, and it was these constant reminders that ensured the stability of the restored democracy. 


\section{List of Figures}

Image Unavailable: Please Consult Caption.

Figure One. Plan of the Athenian Agora at the end of the $5^{\text {th }}$ century. The American School of Classical Studies at Athens, PD 873. Retrieved from https://www.ascsa.edu.gr/resources-

landing/details?source=dc\&id=Agora:Drawing:DA\%203903 (1 July 2019). 
Image Unavailable: Please Consult Caption.

Figure Two. Agora boundary stone c.500 BC. The American School of Classical Studies at Athens. Retrieved from http://agora.ascsa.net/id/agora/monument/boundary $\% 20$ stones $\% 20$ of $\% 20$ the $\% 20$ agora (1 July 2019). 
Image Unavailable: Please Consult Caption.

Figure Three. Roman marble copy of the second Tyrannicide group by Kritias and Nesiotes. Naples Archaeological Museum. Retrieved from

https://en.wikipedia.org/wiki/Harmodius and Aristogeiton (sculpture)\#/media/File:Tiranicidas 04.JPG (1 July 2019). 
Image Unavailable: Please Consult Caption.

Figure Four. Red figure volute krater depicting Herakles in an amazonomachy scene. Euphronios. 550-510 BC. Arezzo National Archaeological Museum, 1465. Retrieved from https://en.wikipedia.org/wiki/Arezzo 1465 vase\#/media/File:Attica, cratere di euphronios, 500470 ac. ca. 02.JPG (1 July 2019). 


\section{Bibliography of Sources}

Alcock, S.E. (2002). Archaeologies of the Greek Past: Landscape, Monuments, and Memories. Cambridge: Cambridge University Press.

Alonso, A.M. (1988). "The Effects of Truth: Re-Presentations of the Past and the Imagining of Community". Journal of Historical Sociology, Vol. 1 No. 1: 33-59.

Ankersmit, F.R. (2005). Sublime Historical Experience. Stanford: Stanford University Press. Assmann, J., Czaplicka, J. (1995). “Collective Memory and Cultural Identity.” New German Critique, No.65: 125-133.

Asssmann, J. (2011). Cultural Memory and Early Civilisation: Writing, Remembrance, and Political Imagination. Cambridge: Cambridge University Press.

Azoulay, V. (2017). The Tyrant Slayers of Ancient Athens. Lloyd, J. (trans.). Oxford: Oxford University Press.

Barash, J.A. (2016). Collective Memory and the Historical Past. Chicago: The University of Chicago Press.

Basso, K.H. (1996). Wisdom Sits in Places: Landscape and Language Among the Western Apache. Albuquerque: University of New Mexico Press.

Battaglia, D. (1992). "The Body in the Gift: Memory and Forgetting in Sabarl Mortuary Exchange." American Ethnologist, Vol. 19 No. 1: 3-18.

Bienenstock, M. (2010). "Is there a duty of Memory? Reflections on a French Debate". Modern Judaism, Vol. 30 No. 3: 332-347.

Boardman, J. (2002). The Archaeology of Nostalgia: How the Greeks Re-Created Their Mythical Past. London: Thames \& Hudson Ltd.

Boegehold, A.L., Camp, J.M. II., Corsby, M., Lang, M., Jordan, D., Townsend, R.F. (1995). The Athenian Agora Volume 28: The Lawcourts at Athens: Sites, Buildings, Equipment, Procedure, and Testimonia. Princeton: The American School of Classical Studies at Athens.

Bonner, R.J. (1924) "Note on the Aristotle Constitution of Athens xxxix.5." Classical Philology, Vol. 19 No.2: 175-176.

Boyer, M.C. (1994). The City of Collective Memory: Its Historical Imagery and Architectural Entertainments. Cambridge: The MIT Press.

Brunnsaker, S. (1971). The Tyrant-Slayers of Kritios and Nesiotes: A Critical Study of the Sources and Restorations. Stockholm: Svenska Institutet i Athen. 
Calame, C. (2009). Poetic and Performative Memory in Ancient Greece. Patton, H. (trans.) Washington D.C.: Centre for Hellenic Studies.

Camp, J.M. II. (1986). The Athenian Agora: Excavations in the Heart of Classical Athens. London: Thames \& Hudson.

Camp, J.M.II. (1990). The Athenian Agora: A Guide to the Excavation and Museum, Fourth Edition Revised. Princeton: American School of Classical Studies at Athens.

Camp, J.M. II. (2010). The Athenian Agora: Site Guide, Fifth Edition. Princeton: American School of Classical Studies at Athens.

Carawan, E. (2013). The Athenian Amnesty and Reconstructing the Law. Oxford: Oxford University Press.

Carsten, J. (1995). "The Politics of Forgetting: Migration, Kinship, and Memory on the Periphery of the Southeast Asian State." The Journal of the Royal Anthropological Institute, Vol. 1 No. 2: 317-335.

Casey, E. (1996). "How to get from Space to Place in a Fairly Short Stretch of Time: Phenomenological Prolegomena" in Sense of Place. Feld, S., Basso, K.H. (eds). Santa Fe: School of American Research Press. Pp. 13-52.

Cohen, D. (2001). “The Rhetoric of Justice: Strategies of Reconciliation and Revenge in the Restoration of Athenian Democracy in 403 BC.” Archives Européennes de Sociologie, Vol. 42, No.2: 335-356.

Confino, A. (1997). “Collective Memory and Cultural History: Problems of Method”. The American Historical Review, Vol.102 No.5:1386-1403.

Connor, W.R. (1988). "Sacred and Secular: Iera kai osia and the Classical Athenian Concept of the State". Ancient Society Vol. 19: 161-188.

Crane, S.A. (1997). "Writing the Individual Back into Collective Memory". The American Historical Review, Vol. 102 No. 5: 1372-1385.

Crosby, M. (1949). "The Altar of the Twelve Gods in Athens". Hysperia Supplements Vol. 8: 82103.

Csapo, E., Miller, M. (1998). “Democracy, Empire, and Art: Toward a Politics of time and Narrative." in Boedeker, D., Raaflaub, K.A. (eds.). Democracy, Empire and the Arts in Fifth-Century Athens. Cambridge: Harvard University Press. Pp. 87-126.

Dessingue, A. (2011). "Towards a Phenomenology of Memory and Forgetting”. Ricoeur Studies, Vol. 2 No.1: 168-178.

Dorjahn, A.P. (1946). Political Forgiveness in Old Athens. Wisconsin: George Banta Publishing Company. 
Dougherty, C. (2009). “Just Visiting: The Mobile World of Classical Athens.” Boys-Stones, G., Graziosi, B., Vasunia, P. (eds.). The Oxford Handbook of Hellenic Studies. Oxford:

Oxford University Press: 391-400.

Dover, K. (1965). Thucydides Book VI. Oxford: Clarendon Press.

Dover, K. (1980). Symposium. Cambridge: Cambridge University Press.

Edwards, M. (1995). Greek Orators - IV: Andocides. Wiltshire: Aris \& Phillips Ltd.

Evans, J.A.S. (1993). "Herodotus and the Battle of Marathon." Historia: Zeitschrift für Alte Geschichte, Bd. 42 H. 3: 279-307.

Fentress, J., Wickham, C. (1992). Social Memory. ALS Humanities E-Book: http://hdl.handle.net/2027/heb.03955.

Field, S., Basso, K.H. (1996). "Introduction” in Sense of Place. Feld, S., Basso, K.H. (eds). Santa Fe: School of American Research Press. Pp. 3-11.

Fingarette, A. (1971). "A New Look at the Wall of Nikomakhos". Hesperia: The Journal of the American School of Classical Studies at Athens Vol. 40 No.3: 330-335.

Finley, M.I. (1965). "Myth, Memory, and History”. History and Theory, Vol. 4 No.3: 281-302.

Finley, M.I. (1971). The Constitution of Athens. Cambridge: Cambridge University Press.

Gardener, P. (2010). Hermeneutics, History and Memory. New York: Routledge.

Garner, R. (1987). Law \& Society in Classical Athens. Kent: Croom Helm Ltd.

Gehrke, H.J. (1985). Stasis: Untersuchungen zu den inneren Kriegen in den griechischen Staaten des 5. und 4. Jahrhunderts v. Chr. München: Beck.

Gernet, L. (1981). The Anthropology of Ancient Greece. Hamilton, J., Nagy, B. (trans). Baltimore: Johns Hopkins University Press.

Grethlein, J. (2010). The Greeks and Their Past: Poetry, Oratory and History in the Fifth Century BCE. Cambridge: Cambridge University Press.

Hansen, M.H. (1978). “Did the Athenian Ecclesia Legislate after 403/2 B.C.?” Greek, Roman and Byzantine Studies, Vol.20, No.1: 27-53.

Harding, P. (2005). Athens Transformed, 404-262 BC. New York: Routledge.

Hereward, D. (1952). "New Fragments of IG II² 10." The Annual of the British School at Athens Vol. 47: 102-117.

Ismard, P. (2010). La cité des réseaux. Athènes et ses associations, vie-ier siècle av. J.-C. Paris: Publications de la Sorbonne.

Johnston, R.W., Mulroy, D. (2009). “The Hymn to Hermes and the Athenian Altar of the Twelve Gods." The Classical World Vol. 103 No. 1: 3-16. 
Kremmydas, C. (2012). Commentary on Demosthenes Against Leptines: With Introduction, Text, and Translation. Oxford: Oxford University Press.

Krentz, P. (1982). The Thirty at Athens. Ithaca: Cornell University Press.

Langdon, M.K. (1991). "Poletai Records" in Lalonde, G.V., Langdon, M.K., Walbank, M. The Athenian Agora Volume 19: Results of Excavations Conducted by The American School of Classical Studies at Athens. Princeton: The American School of Classical Studies at Athens.

Lavelle, B. (1993). The Sorrow and the Pity: A Prolegomenon to a History of Athens Under the Peisistratids, c. 560-510 BC. Stuttgart: Franz Steiner Verlag.

Lewis, D. (1988). The tyranny of the Pisistratidae". In Boardman, J., Hammond, N. Lewis, D., Otswald, M. (eds.) The Cambridge Ancient History, 287-302. Cambridge: Cambridge University Press.

Long, C.R. (1987). “The Twelve Gods of Greece and Rome.” Études préliminaires aux religions orientales dans l'Empire romain Vol. 107: 1-372.

Loraux, N. (2002). The Divided City. Pache, C., Fort, J. (trans.). New York: Zone Books.

Ma, J. (2009). “The City of Memory.” Boys-Stones, G., Graziosi, B., Vasunia, P. (eds.). The Oxford Handbook of Hellenic Studies. Oxford: Oxford University Press: 248-259.

MacDowell, D.M. (1963). Athenian Homicide Law in the Age of the Orators. Manchester: Manchester University Press.

Meritt, B.D. (1936). “Greek Inscriptions.” Hesperia: The Journal of the American School of Classical Studies at Athens Vol. 5 No. 30: 355-430.

Meyer, E.A. (2013). "Inscriptions as Honors and the Athenian Epigraphic Habit". Historia: Zeitschrift für Alte Geschichte Bd. 62, H. 4: 453-505.

Middleton, D.F. (1982). “Thrasyboulos' Thracian Support.” The Classical Quarterly, Vol. 32 No.2: 298-303.

Mitchell, L. (2006). "Tyrannical Oligarchs at Athens.” Lewis, S. (ed.) Ancient Tyranny. Edinburgh: Edinburgh University Press: 178-187.

Nemetz-Carlson, L.T. (2012). "Athenian History and Democracy in the Monumental Arts During the Fifth Century BC". PhD dissertation. Ohio State University.

Nora, P. (1989). “Between Memory and History: Lex Lieux de Mémoire.” Representations No. 26: 7-24.

Nora, P. (2001). Rethinking France: Les Lieux de Mémoire Volume I. Jordan, D.P. and Trouille, M. (Trans.). Chicago: University of Chicago Press. 
Nora, P. (2006). Rethinking France: Les Lieux de Mémoire Volume II. Jordan, D.P. (Trans.). Chicago: University of Chicago Press.

Nora, P. (2009). Rethinking France: Les Lieux de Mémoire Volume III. Jordan, D.P. (Trans.). Chicago: University of Chicago Press.

Nora, P. (2010). Rethinking France: Les Lieux de Mémoire Volume IV. Jordan, D.P. (Trans.). Chicago: University of Chicago Press.

Ober, J. (1996). The Athenian Revolution: Essays on Ancient Greek Democracy and Political Theory. Princeton: Princeton University Press.

Ober, J. (2005a). Athenian Legacies: Essays on the Politics of Going on Together. Princeton: Princeton University Press.

Ober, J. (2005b). "Social Science History, Cultural History, and the Amnesty of 403 B.C." Ober, J. (ed.) Essays on the Politics of Going on Together. Princeton: Princeton University Press: 171-182.

Ober, J. (2005c). "Culture, Thin Coherence, and the Persistence of Politics." Ober, J. (ed.) Essays on the Politics of Going on Together. Princeton: Princeton University Press: 69-90.

Osborne, R. (2009). “Urban Landscape and Architecture.” Boys-Stones, G., Graziosi, B., Vasunia, P. (eds.). The Oxford Handbook of Hellenic Studies. Oxford: Oxford University Press: 238-247.

Popular Memory Group. (1982). “Popular Memory: Theory, Politics, Method.” In Making Histories: Studies in History-Writing and Politics. Johnson, R., McLennan, G. Schwarts, B. Sutton, D. (eds.). London: Hutchinsons \& Co. Ltd: 205-252.

Rhodes, P.J. (2007). "Oaths in Political Life.” Horkos: The Oath in Greek Society. Sommerstein, A.H., Fletcher, J. (eds). Exeter: Bristol Phoenix Press: 11-25.

Rhodes, P.J. (2009). "Epigraphy.” Boys-Stones, G., Graziosi, B., Vasunia, P. (eds.). The Oxford Handbook of Hellenic Studies. Oxford: Oxford University Press: 709-719.

Ricœur, P. (2004). Memory, History, Forgetting. Blamey, K, Pellauer, D. (trans.) Chicago: University of Chicago Press.

Rober, D.A. (2013). "Ricoeur, Metz, and the Future of Dangerous Memory". Literature \& Theology, Vol. 27 No.2:196-207.

Rösler, W. (2009). "Books and Literacy.” (Spiegel, F. trans.). Boys-Stones, G., Graziosi, B., Vasunia, P. (eds.). The Oxford Handbook of Hellenic Studies. Oxford: Oxford University Press: 432-441.

Rowlands, M. (1993). "The Role of Memory in the Transmission of Culture." World Archaeology, Vol. 25 No. 2: 141-151. 
Rubel, A., Vickers, M. (2014). Fear and Loathing in Ancient Athens: Religion and Politics During the Peloponnesian War. London: Routledge.

Rubinstein, L. (2009). “Oratory.” Boys-Stones, G., Graziosi, B., Vasunia, P. (eds.). The Oxford Handbook of Hellenic Studies. Oxford: Oxford University Press: 505-517.

Russell, N. (2006). “Collective Memory before and after Halbwachs”. The French Review, Vol. 79 No.4: 792-804.

Samons, L. J. II. (2011). "Marathon and Athenian "Collaboration.” Arion, A Journal of Humanities and the Classics. Third Series, Vol 18 No. 3: 155-158.

Shear, J.L. (2007). "The Oath of Demophantos and the Politics of Athenian Identity."

Sommerstein, A.H., Fletcher, J. (eds). Horkos: The Oath in Greek Society. Exeter: Bristol Phoenix Press: 148-160.

Shear, J.L. (2011). Polis and Revolution: Responding to Oligarchy in Classical Athens.

Cambridge: Cambridge University Press.

Shear, J.L. (2013). "Religion and the Polis: The Cult of the Tyrannicides at Athens." Kernos: Revue Internationale et Pluridisciplinaire de Religion Grecque Antique, No. 25: 27-56.

Shear, T.L. Jr. (1937). “The Campaign of 1936.” Hesperia: The Journal of the American School of Classical Studies at Athens Vol. 6 No. 3: 333-381.

Sheppard, A. (2016). “Aristophanes' Ecclesiazvsae and the remaking of the patrios politeia". The Classical Quarterly: 1-21.

Siegel, M. (2002). "History is the Opposite of Forgetting: The Limits of Memory and the Lessons of History in Interwar France." The Journal of Modern History, Vol. 74, No.4: 770-800.

Sommerstein, A.H. (2007). "Introduction.” Horkos: The Oath in Greek Society. Sommerstein, A.H., Fletcher, J. (eds). Exeter: Bristol Phoenix Press: 1-10.

Steinbock, B. (2013). Social Memory in Athenian Discourse: Uses and meanings of the Past. Ann Arbor: The University of Michigan Press.

Stem, R. (2003). "The Thirty at Athens in the Summer of 404." Phoenix, Vol. 57 No. 1: 18-34. Stroud, R.S. (1971) “Greek Inscriptions Theozotides and the Athenian Orphans.” Hesperia: The Journal of the American School of Classical Studies at Athens, Vol. 40 No. 3: 280-301. Stroud, R.S. (1971). "Greek Inscriptions Theoztides and the Athenian Orphans". Hesperia: The Journal of the American School of Classical Studies at Athens Vol. 40 No.3: 280-301. Stroud. R.S. (1968). Drakon's Law on Homicide. Berkeley: University of California Press. Taylor, A.C. (1993). "Remembering to Forget: Identity, Mourning, and Memory Among the Jivaro." Man New Series, Vol. 28 No.4: 653-678. 
Taylor, M.W. (1991). The Tyrant Slayers: The Heroic Image in Fifth Century B.C. Athenian Art and Politics, Second Edition. Salem: Ayer Company Publishers Inc.

Teegarden, D. (2014). Death to Tyrants!: Ancient Greek Democracy and the Struggle Against Tyranny. Princeton: Princeton University Press.

Thompson, H.A. (1937). "Buildings on the West Side of the Agora." Hesperia: The Journal of the American School of Classical Studies at Athens Vol. 6 No. 1: 1-226.

Thompson, H.A. (1950). "Excavations in the Athenian Agora: 1949." Hesperia: The Journal of the American School of Classical Studies at Athens Vol. 19 No. 4: 313-337.

Thompson, H.A., Wycherley, R.E. (1972). The Athenian Agora Volume 15: Results of Excavations Conducted by the American School of Classical Studies at Athens. Princeton: The American School of Classical Studies at Athens.

Van Dyke, R.M. (2003). “Archaeologies of Memory: An Introduction.” Alcock, S., Van Dyke, R.M. (eds). Archaeologies of Memory. Oxford: Wiley-Blackwell.

Vanderpool, E. (1974). "The "Agora" of Pausanias I, 17, 1-2." Hesperia: The Journal of the American School of Classical Studies at Athens Vol. 43 No. 3: 308-310.

Vlassopoulos, K. (2007). "Identity, Experience and Democracy in Classical Athens". The Classical Quarterly, New Series Vol. 57 No. 1: 33-52.

Walbank, M.B. (1982). "The Confiscation and Sale by the Poletai in 402/1 B.C. of the Property of the Thirty Tyrants". Hesperia: The Journal of the American School of Classical Studies at Athens Vol. 51 No.1: 74-98.

Weinrich, Harald. (1997). Lethe: The Art and Critique of Forgetting. Rendall, S. (Trans.) Ithaca: Cornell University Press.

Wolpert, A. (2002). Remembering Defeat: Civil War And Civic Memory In Ancient Athens. Baltimore: The Johns Hopkins University Press

Wolpert, A. (2006). “The Violence of the Thirty Tyrants.” Lewis, S. (ed.) Ancient Tyranny. Edinbburgh: Edinburgh University Press: 213-222.

Wycherley, R.E. (1957). The Athenian Agora Volume 3: Literary and Epigraphical Testimonia. Princeton: The American School of Classical Studies at Athens.

Wycherley, R.E. (1959). "Pausanias in the Agora of Athens". Journal of Greek, Roman, and Byzantine Studies Vol.2: 23-44.

Wycherley, R.E. (1962). How the Greeks Built Cities. London: Macmillan \& Co. Ltd. Wycherley, R.E. (1978). The Stones of Athens. Princeton: Princeton University Press. 
Wycherley, R.E. (1988). "Rebuilding in Athens and Attica”. In Boardman, J., Hammond, N.

Lewis, D., Otswald, M. (eds.) The Cambridge Ancient History, 206-222. Cambridge:

Cambridge University Press.

Young, J.E. (1993). The Texture of Memory: Holocaust Memorials and Meaning. New Haven: Yale University Press. 